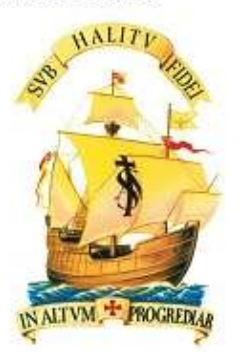

Cuadernos de Investigación Histórica No 36 La hazaña española: Magallanes y Elcano Año: 2019

DOI: https://doi.org/10.51743/cih.80

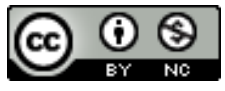

\title{
500 AÑOS DE LA EXPEDICIÓN ESPAÑOLA QUE COMPLETÓ LA PRIMERA CIRCUNNAVEGACIÓN DE LA TIERRA
} 500 YEARS OF THE SPANISH EXPEDITION THAT COMPLETED THE FIRST CIRCUMNAVIGATION OF THE EARTH

JOSÉ LUIS SÁNCHEZ GARCÍA Director del Seminario de Historia Cisneros. Fundación Universitaria Española

JUAN MARÍA DÍEZ SANZ

Profesor de Filosofía.

Universidad Católica de Valencia

Agradecimientos:

Quiero agradecer, como director del Seminario de Historia Cisneros de la FUE, al jurista y amante de la historia, D. Federico Sánchez Raymundo, que en su día dedicara su tiempo a hablarme sobre este tema capital de la historia de España y de la humanidad, contándome toda la gesta pormenorizadamente, desde el principio hasta el fin, y motivándome a realizar, no solo este artículo, sino la propuesta de dedicar íntegramente, este año 2019, en la Fundación Universitaria Española, a la expedición de Magallanes y Elcano.

También quiero agradecer a D. Javier Peris Escribá, creativo y consultor, por su colaboración en el año de Magallanes Elcano, por todas sus aportaciones y trabajos preliminares para el video que se realizará próximamente y que ha motivado, también desde ese proyecto del Equipo Jorge Juan, este trabajo.

De manera particular, a la Real Academia de la Historia española, por su docto Informe sobre sobre la Primera Circunnavegación a la tierra, de 10 de marzo de 2019, donde al margen de las controversias del momento, pone de relieve la autoría española de la expedición de acuerdo con los hechos históricos, basándose en fuentes históricas acreditadas y contrastables. 
RESUMEN:

La Real Academia de Historia ha publicado un informe con motivo del V centenario de la Primera Circunnavegación de la Tierra, que fue realizada por Juan Salvador Elcano, a la que nos unimos. En la presente investigación, realizamos una revisión de los principales hechos constatados de la expedición: Magallanes, fue un marino de origen portugués nacionalizado español, la empresa fue auspiciada por la Corona Española, por el rey Carlos I, confiriéndole la dimensión universal que proviene de la catolicidad que los Reyes Católicos imprimieron a la institución monárquica española y que tiene su origen en el reino Godo. La expedición se desarrolla ya al inicio de la Edad Moderna, en un contexto de rivalidad con la nación portuguesa por el comercio de las especias y la delimitación de los ámbitos de influencia de ambas naciones, que había quedado establecida en el Tratado de Tordesillas, legalidad internacional que la Corona exige sea respetada y la expedición cumple, como ha recordado Felipe VI. La financiación de la empresa contó con el respaldo de capital privado tanto de comerciantes burgaleses, como de la Iglesia, en la persona del obispo de Burgos. Realizamos, además, una crónica de la expedición circunnavegadora con los principales hechos acontecidos y referimos los principales descubrimientos: la constatación de la esfericidad de la Tierra, el descubrimiento del Estrecho de Magallanes, la apertura de una nueva ruta comercial hacia las Indias, los descubrimientos astronómicos de nuevas galaxias como las Nubes de Magallanes, los nuevos conocimientos etnográficos y de fauna y flora de latitudes diversas, el descubrimiento de nuevas enfermedades como el escorbuto, una forma de avitaminosis C, y, por último, una decisiva ampliación del mundo conocido que supuso la primera globalización del mundo.

Palabras claves: Magallanes, Elcano, V centenario de la Primera Circunnavegación

\footnotetext{
ABSTRACT

The Royal Academy of History has published a report on the occasion of the V centenary of the First Circumnavigation of the Earth, which was carried out by Juan Salvador Elcano, to which we join. In the present investigation, we carried out a review of the main facts of the expedition: Magallanes, was a sailor of Portuguese nationalized Spanish origin, the company was sponsored by the Spanish Crown, by King Carlos I, conferring the universal dimension that comes from the catholicity that the Catholic Monarchs printed to the Spanish monarchical institution and that has its origin in the Godo kingdom. The expedition takes place already at the beginning of the Modern Age, in a context of rivalry with the Portuguese nation for the spice trade and the delimitation of the spheres of influence of both nations, which had been established in the Treaty of Tordesillas, legality international that the Crown demands is respected and the expedition complies, as Felipe VI recalled. The financing of the company was backed by private capital from both Burgos
} 
merchants and the Church, in the person of the Bishop of Burgos. We also make a chronicle of the

Keywords.

Magallanes, Elcano, V centenary of the First Circumnavigation

\section{INTRODUCCIÓN}

耳 $\mathrm{n}$ el presente artículo queremos rememorar una gran gesta de la humanidad Drotagonizada por nuestra nación al inicio de la Edad Moderna y que reconfiguró la imagen del mundo, ya en su época, y para la posteridad. Queremos precisar su significación, señalar su relevancia $\mathrm{y}$, sobre todo, los presupuestos gnoseológicos desde los que se realiza, que exceden con mucho la mera suposición de una proeza humana culminada con una serie de descubrimientos geográficos o cartográficos destacados para su época.

Queremos indagar en su significado al margen de las controversias suscitadas con motivo de la conmemoración del $\mathrm{V}$ centenario de la empresa que realizó la Primera Circunvalación del Globo Terrestre. Parece que en nuestra nación es complicado conmemorar cualquier hazaña histórica sin que esté exenta de polémica. Creemos que la mejor forma de investigar el pasado, en realidad probablemente sea la única, es remontarse a los hechos constatados, sirviéndose de fuentes fiables para tratar de esclarecer su significación.

En nuestra investigación, vamos a diferenciar los datos referidos a los hechos constatados, verificables y respaldados por fuentes fiables, de la posible interpretación o significación de los mismos, evitando el riesgo de la acumulación de datos al que propende la historiografía contemporánea y del que debe cuidarse la ciencia histórica, según denunciaba Julián Marías en el prólogo de su obra España inteligible ${ }^{I}$, para no quedarnos en un mero behaviorismo de los hechos ${ }^{2}$, en un repertorio amorfo de datos o colección de efemérides, "a la puerta de la historia, sin entrar en ella"3 advertía el filósofo, evitando el compromiso y la responsabilidad de tener que cifrar su significación o señalar su relevancia. En esta misma línea, un experto en el tema como José Luis Comellas, en el primer capítulo de su estudio, donde recrea el marco histórico de la expedición circunvaladora, realiza una consideración metodológica que consideramos relevante:

\footnotetext{
${ }^{1}$ MARÍAS, J., España inteligible. Razón histórica de las Españas (1985), Alianza Editorial, Madrid, 2005.

${ }^{2}$ Ibidem, p. 13

${ }^{3}$ Ibidem.
} 
"Hacer historia partiendo de un punto fijo como si ese punto fuese el comienzo de la historia misma es como partir de cero en medio de una realidad continua, y eso nos impide comprender el cómo y el por qué de las cosas que en un momento acontecen"4

Nuestra contribución, aunque modesta, pretende ayudar a configurar una hermenéutica apropiada y rigurosa de la historia, una visión que parte de los hechos pero no se queda en ellos, sino que trata de establecer las condiciones de inteligibilidad de las trayectorias que la hicieron posible, a partir del carácter proyectivo y vectorial de la acción humana que hace que la estructura social, como pretensión colectiva, sea programática ${ }^{5}$.

La distinción metodológica de la que partimos, que diferencia entre los hechos y la significación de los mismos, tiene su razón de ser y su fundamento último en la pertinente distinción epistemológica entre inteligencia y razón ${ }^{6}$, que expone y emplea nuestro maestro D. Julián Marías y que ejemplifica magistralmente en su aproximación al estudio de la historia de nuestra nación expuesto en su obra España inteligible, razón histórica de las Españas ${ }^{7}$.

Por ello, en el presente artículo queremos centrarnos primeramente en los hechos, tal como los recoge la Real Academia de la Historia (RAH) en su Informe sobre la Primera Circunnavegación a la tierra ${ }^{8}$, basados en las fuentes

${ }^{4}$ COMELLAS GARCÍA-LLERA, JL, La primera vuelta al mundo, Rialp, Madrid, 2012, p. 12.

${ }^{5}$ Marías postula que tenemos que comprender la acción humana en su carácter proyectivo: "Toda situación es inestable, es decir, viene de una anterior y va a otra siguiente. Como las vidas humanas son trayectorias, proyectos, presiones, cuya imagen puede ser la flecha, una sociedad es un sistema de fuerzas orientadas, es decir, vectorial. La misma estructura social tiene trayectoria, es programática, viene de un pasado y tiende hacia un futuro, ambos presentes en ella" (MARÍAS, J., España inteligible. Razón histórica de las Españas, Alianza Editorial, Madrid, 2005, p.31).

${ }^{6}$ Julián Marías sostiene que es, antropológicamente pertinente y epistemológicamente necesario, distinguir entre inteligencia y razón: entre la inteligencia como capacidad receptiva y de procesamiento de datos, que genera información, y la razón, propiamente dicha, que supone establecimiento de conexiones significativas, para conformar sentido y generar conocimiento. Por lo tanto, este enfoque supone que información y conocimiento no son sinónimos, ni términos epistemológicamente equivalentes o intercambiables. La racionalidad va más allá de la inteligencia al permitir establecer las condiciones de inteligibilidad de los hechos referidos, su significación precisa y su relevancia, tal como hemos señalado en otros trabajos precedentes, fundamentados en la epistemología de Julián Marías Aguilera derivada de su obra Antropología metafísica (Revista de Occidente, Madrid, 1970) en investigación realizada con Juan María Díez Sanz. Véase: SÁNCHEZ GARCÍA, JL., DÍEZ SANZ, JM., y PÉREZ RUIZ, S., "La discapacidad capacita, proyecto y tarea: el desarrollo de las capacidades humanas". En IBÁÑEZ MARTÍN, J.A., y FUENTES, J.L., (edit.) Educación y capacidades. Hacia un nuevo enfoque del desarrollo humano. Ed. Dykinson, Madrid, 2017, p. 285. ISBN: 978-84-9148-202-4.

${ }^{7}$ MARÍAS, J., España inteligible. Razón histórica de las Españas (1985), Alianza Editorial, Madrid, 2015.

${ }^{8}$ REAL ACADEMIA DE LA HISTORIA, Informe sobre la Primera Circunnavegación a la tierra, 10 de marzo de 2019. Disponible en http://www.rah.es/informe-de-la-real-academia-de-lahistoria-sobre-la-primera-circunnavegacion-a-la-tierra/ 
acreditadas disponibles y verificables, fundamentalmente la documentación disponible en el Archivo General de Indias, en Patronato y en Contratación, Contaduría e Indiferente General, Protocolos, así como en la bibliografía acreditada disponible, entre los que destaca la obra de Juan Gil Fernández, y de Cristóbal Bernal Chacón, así como los fondos bibliográficos de la propia Biblioteca de la Real Academia.

Posteriormente indagaremos en la significación de tales hechos tratando de cifrar su significación desde las trayectorias y los presupuestos que posibilitaron su concepción y su realización en distintos ámbitos: económico, político, cartográfico, científico-cultural, religioso, etc. considerando las aportaciones de los estudiosos y expertos en el tema.

\section{PRINCIPALES HECHOS CONSTATADOS.}

En nuestra investigación queremos partir del citado informe elaborado por la Real Academia de la Historia ${ }^{9}$ y poner de relieve los hechos, unos ya publicados y otros inéditos ${ }^{10}$, en todo caso, hechos históricos objetivos ${ }^{11}$, que esta institución avala como contrastados basándose en fuentes acreditadas. Veamos algunos de los más importantes:

\subsection{Magallanes, un marino portugués nacionalizado español}

Quizá lo primero sea hablar del marino que encabeza y da nombre a la histórica expedición, D. Fernando de Magallanes, que nació en Portugal (Sabrosa, Oporto, 1480) en el seno de una familia nobiliaria y que prestó servicios a la Corona de Portugal ${ }^{12}$, hasta que, tras una serie de desavenencias, los portugueses decidieron prescindir de sus servicios ${ }^{13}$.

\footnotetext{
${ }^{9}$ Ibidem.

${ }^{10}$ Ibidem, p. 1.
}

${ }^{11}$ Ibidem.

${ }^{12}$ El Dr. José Luis Comellas, catedrático de Historia en Sevilla, sintetiza los antecedentes de Magallanes, en lo referente a la expedición circunnavegadora, de la forma siguiente: "En 1515 participó en la expedición organizada por el virrey Alburquerque destinada a la conquista de Malaca. Desde los tiempos de Marco Polo, ningún europeo había llegado tan lejos. (...) En Malaca encontraron los portugueses un excelente mercado de especias, que los navegantes transportaban desde las islas del Maluco o Molucas, situadas todavía más allá. Fernando de Magallanes pretendió alcanzar aquellas fabulosas islas, acompañando a un grupo de audaces aventureros en que figuraba también su amigo Francisco Serrano. La expedición fracasó, aunque Serrano después de varios naufragios consiguió llegar a Ternate, una de aquellas islas tan buscadas. Desde allí pudo mantener una interesante correspondencia con Magallanes. Las Molucas estaban muy lejos; en sí eran muy pobres, pues producían malas cosechas... excepto las maravillosas especias, que los naturales vendían a buen precio a cambio de los artículos que necesitaban. La zona era peligrosa por sus tempestades, pero valía la pena llegar a ellas. 
Hay constancia de su procedencia lusa en la documentación oficial de nuestra nación, el informe de la Real Academia destaca:

"Las mismas Capitulaciones de Valladolid de 1518 así lo avalan, cuando el Rey Carlos I dice «por cuanto vos Fernando de Magallanes, caballero natural del reino de Portugal...»."

Luego no hay dudas sobre la procedencia del ilustre marino como tampoco sobre los servicios que prestó a la Corona portuguesa en diversas expediciones al Índico, antes de su venida a España. Pero también quedan claras sus desavenencias con el rey de Portugal al que había servido y las razones de su instalación en España:

"Pero ya en 1517, Magallanes, enojado con D. Manuel de Portugal por no reconocer sus méritos, decide abandonar su país, dejar de servir a su Rey y viajar a España, concretamente a Sevilla, donde se instaló, contrajo matrimonio y desde entonces estuvo al servicio del Rey Carlos I, castellanizando su nombre portugués, Fernão de Magalhaes por Fernando de Magallanes." 15

Magallanes viene a España contrariado, como recoge el propio informe de la RAH, y como avalan numerosos autores, como Comellas, e incluso el célebre grabador y aficionado historiador Theodor De Bry ${ }^{16}$, ya en el mismo siglo XVI.

No parece que Magallanes se trasladase a nuestra nación temporalmente, para una estancia temporal, para probar fortuna fuera de su tierra natal. Más bien parece que viene a España, disgustado y repudiado por el rey Manuel I de Por-

Magallanes nunca pudo reunirse con Serrano, pero conservó siempre el sueño de llegar un día a aquellas islas remotas, peligrosas, donde se producían las famosas especias." (COMELLAS GARCÍA-LLERA, JL, La primera vuelta al mundo, Rialp, Madrid, 2012, p. 31).

${ }^{13}$ Respecto a las razones de tales desavenencias, explica Comellas, sobre la vida de Magallanes: "En la India se dedicó a los negocios, y se arruinó. Regresó a Portugal. Ansioso de aventuras, participó en una expedición a Marruecos, y fue gravemente herido en la batalla de Azamor. Quedaría cojo para toda la vida. Acusado de vender artículos para el enemigo, perdió la confianza del rey don Manuel el Afortunado. Pidió una recompensa por sus hazañas, que le fue denegada. Caído en desgracia, decidió correr mejor suerte en España.

Como Colón, fue un hombre que, desengañado en Portugal, cambió de fidelidad para cumplir sus propósitos. Su idea estaba clara: pedir autorización y ayuda para llegar a las Molucas, la tierra de las especias. Las cartas de Serrano y las distancias exageradas por los portugueses le permitían suponer, o conjeturar al menos, que aquellas islas caían en el hemisferio español." (COMELLAS GARCÍA-LLERA, JL, Idem, pp. 31-32).

${ }^{14}$ REAL ACADEMIA DE LA HISTORIA, idem, p.2.

${ }^{15}$ Ibidem.

${ }^{16}$ Theodore De Bry, afirma: "Fernando de Magallanes, ofendido por el rey de Portugal, dirigiose al emperador Carlos $\mathrm{V}$ y le señaló que competían y pertenecían las islas Molucas a Castilla y que navegando hacia poniente esperaba encontrar un mar en las Indias Occidentales por el cual pensaban alcanzar los mares del Sur y de allí las islas Molucas." (De Bry T., América, 1590-1634, prólogo de John H. Elliott, Madrid, Siruela, 1992, p. 172). 
tugal con una voluntad de instalación y asentamiento definitivo en nuestra nación. De hecho, diversos estudiosos sobre su persona, como el investigador del CSIC, Salvador Bernabéu ${ }^{17}$ ó el académico de la RAE, Juan Gil Fernández ${ }^{18}$, no dudan en considerarlo un exiliado en España y, en el caso de Bernabéu, literalmente, un nacionalizado español. ${ }^{19}$

El hecho histórico objetivo es que Magallanes se muda a España, se instala en Sevilla, contrae matrimonio en la capital hispalense y hasta modifica y castellaniza su nombre. Siendo muy relevantes y significativos todos estos datos de su vida, muestra evidente de ese arraigo en España, la Real Academia todavía destaca otro más:

"Y algo muy importante: cuando antes de partir la expedición dictó y firmó su testamento en el Alcázar de Sevilla, instituyó un mayorazgo en el que dejaba heredero a su hijo Rodrigo, nacido en Sevilla y, si éste falleciese sin descendencia, impone a su familia portuguesa que quien lo herede debería castellanizar su apellido, llevar sus armas y vivir en Castilla." 20

Antes de embarcarse en una expedición que preveía tan fundadamente arriesgada (de hecho, le costaría la vida), Fernando de Magallanes hace testamento en Sevilla con su apellido castellanizado, en favor de su hijo Rodrigo, nacido en Sevilla, y dejando constancia expresa de su voluntad de adscripción de su nombre, persona y descendencia a la Corona de Castilla. Este hecho no parece un simple gesto de deferencia hacia la nueva tierra que lo acoge y al Rey que le da trabajo, sino muestra de un arraigo personal, familiar y laboral, de un compromiso con Sevilla, con Castilla $\mathrm{y}$, en definitiva, con la nación española que lo acoge y le ofrece un proyecto. Por todo ello, concluye la Real Academia:

"Se considera por tanto un castellano más."21

${ }^{17}$ Tal como refiere Salvador Bernabéu, del Consejo Superior de Investigaciones Científicas (CSIC), en la Escuela de Estudios Hispanoamericanos de Sevilla: "El objetivo del navegante exiliado en Castilla (referido a Magallanes) es el mismo que concibió y defendió hasta su muerte Cristóbal Colón: llegar a Asia por una ruta occidental." BERNABÉU, S., "Magallanes: Retrato de un hombre". En YUSTE LÓPEZ, C.; PINZÓN RÍOS, G., A 500 años del hallazgo del Pacífico. La presencia novohispana en el Mar del Sur, Ciudad de México, Universidad Nacional Autónoma de México, Instituto de Investigaciones Históricas, 2016. p, 21, disponible en:

http://www.historicas.unam.mx/publicaciones/publicadigital/libros/hallazgo_pacifico/novohispan a.html

${ }^{18}$ GIL FERNÁNDEZ, J., El exilio portugués en Sevilla. De los Braganza a Magallanes. Sevilla, Fundación Cajasol, 2009.

${ }^{19}$ BERNABÉU, S., idem., p. 23.

${ }^{20}$ REAL ACADEMIA DE LA HISTORIA, idem, p. 2.

${ }^{21}$ Ibidem. 
Realmente, como se constata por los datos disponibles y los hechos acreditados, controversias interesadas al margen, no cabe duda de que Fernando de Magallanes, aunque nacido en Portugal, se naturalizó ${ }^{22}$ español: se asentó libremente en España, cambió y castellanizó su nombre por libre voluntad, testamentó en nuestra nación a favor de su descendencia para la que dispuso heredar en Castilla, en una época en que el linaje quedaba ligado a la tierra, pero además, porque en la empresa que le dio fama inmortal iba al servicio de la Corona española, a la que es de justicia añadir, que sirvió lealmente hasta su trágico final. Ciertamente, su mismo fallecimiento en el remoto archipiélago de Mactán, en Filipinas, constituye, en términos castrenses, un acto de servicio y lealtad final a la nación española. Por lo tanto, parece no solo razonable, sino incluso de justicia, considerarlo un marino español.

Sobre la expedición circunnavegadora y la persona de Magallanes, el investigador Salvador Bernabéu del CSIC, oportunamente, puntualiza que:

"Es un error extendido considerar a Magallanes como el urdidor del viaje que dio la vuelta al mundo por primera vez, incluso considerándolo a él mismo como el primero en realizarlo., 23

Tales errores se deben probablemente a que, como indica Comellas, "más de la mitad de los relatos de la primera vuelta al mundo son intencionalmente biografías de Magallanes" ${ }^{24}$. Como es sabido, el marino que decide, en medio de una gran incertidumbre, y logra la circunnavegación es Juan Sebastián Elcano. Aunque al nombre de Magallanes queda ligado, como subraya el investigador del CSIC, al descubrimiento de cuatro áreas del globo ignotas en su tiempo: el sur argentino, el estrecho que lleva su nombre, el océano Pacífico en toda su extensión y el archipiélago filipino. Por todo lo cual, no duda en calificarlo como "uno de los principales descubridores de todas las épocas" 25.

\subsection{Una expedición española auspiciada por la Corona}

El encuentro con la Corona fue un momento decisivo en la vida de Magallanes y en el devenir de la expedición. Sobre la negociación con el Rey Carlos I, para alcanzar un acuerdo que posibilitase la empresa, señala la Real Academia, que:

\footnotetext{
${ }^{22}$ Hoy diríamos se nacionalizó español, como bien hacen el investigador Salvador Bernabéu y el académico de la lengua Juan Gil Fernández, aunque creemos que la expresión realmente apropiada, acorde al momento histórico, sería la de se naturalizó. Ciertamente, equivaldría a lo que hoy lo expresaríamos, con toda propiedad, como una nacionalización, con todas las consecuencias jurídicas, sociales, administrativas, laborales, etc. que ello implica.

${ }^{23}$ BERNABÉU, S., Ibidem.

${ }^{24}$ COMELLAS GARCÍA-LLERA, JL, La primera vuelta al mundo, Rialp, Madrid, 2012, p. 30.

${ }^{25}$ BERNABÉU, S., Ibidem.
} 
"El 18 de Marzo de 1518 Magallanes viajó a Valladolid a presentar su proyecto, el de encontrar el paso a las islas de la Especiería, al Rey Carlos I y firmó con él las Capitulaciones «...queriéndonos hacer señalado servicio, os obligáis descubrir en los términos que nos pertenecen e son nuestros en el mar océano dentro de los límites de nuestra demarcación islas y tierra firme...»."26

Los acuerdos alcanzados quedaron reflejados en las denominadas Capitulaciones de Valladolid, de 22 de marzo de 1518, en ellas quedaban fijadas las obligaciones para ambas partes.

Lo decisivo de tal encuentro es que Magallanes convence a Carlos I de la posibilidad de alcanzar las islas de la Especiería, navegando por una nueva ruta hacia el Oeste, que supone localizar un paso marítimo hacia el entonces denominado Mar del Sur, tal como había sido denominado por su descubridor Nuñez de Balboa en 1513, pero, sobre todo, el marino convence al Rey de España de que las islas buscadas quedan situadas en territorio de jurisdicción española conforme a los acuerdos suscritos con Portugal.

"En el tratado de Tordesillas (1494), al estipularse en base a la bula papal de Alejandro VI la partición del planeta en dos mitades, tuvo lugar el corrimiento hacia el oeste del meridiano divisorio hasta los 370 grados con la repercusión en el hemisferio austral de que Australia quedara dividida por su parte central por una línea que hoy coincide con la separación del estado de Australia Occidental de los demás de dicho país. La aspiración de la parte española a las islas de la Especiería, supuso el planteamiento de cómo llegar a ellas, si es que resultaran situadas en el hemisferio occidental. En un principio se proyectó alcanzarlas por la vía del cabo de Buena Esperanza (recuérdese la capitulación de Juan Díaz de Solís en 1512, que no llegó a tener efecto); pero pasados varios años se impuso la idea de abordarlas por occidente, ribeteando las tierras del Nuevo Mundo y navegando por un mar de insospechadas dimensiones." 27

Sin duda, la convicción de la potestad española sobre las Molucas, con arreglo a la legalidad internacional ${ }^{28}$, es un factor decisivo para conseguir no solo el

${ }^{26}$ REAL ACADEMIA DE LA HISTORIA, idem, p. 2.

${ }^{27}$ FERNÁNDEZ-SHAW, C.M., Connotaciones españolas en el Pacífico austral. En INSTITUTO DE HISTORIA Y CULTURA NAVAL, XIII Jornadas de Historia Marítima: Álvaro de Mendaña: el Pacífico y su dimensión histórica. Cuadernos Monográficos del Instituto de Historia y Cultura Naval, n²6, Madrid, 1995, p. 47.

${ }^{28}$ Comellas aporta un dato muy relevante y es el convencimiento de Magallanes de que los portugueses probablemente exageraban las distancias hasta las islas de las especias para disuadir a otros de intentarlo y proteger así su monopolio: "Las cartas de Serrano y las distancias exageradas por los portugueses le permitían suponer, o conjeturar al menos, que aquellas islas caían en el 
beneplácito de la Corona al proyecto, sino su implicación y la implementación definitiva de la expedición.

"Ya hemos aludido a las noticias llegadas a la Corte española sobre la posibilidad de que las islas Molucas se encontrasen en la zona asignada a España y todavía no halladas por los portugueses, estimularon al Emperador Carlos a disponer la formación de una serie de expediciones exploratorias, la primera encomendada al portugués Fernando de Magallanes, quien conocía el océano Indico y había doblado el cabo de Buena Esperanza." ${ }^{29}$

Por su conocimiento sobre el terreno de los remotos lugares donde crecen las especias y sus antecedentes ${ }^{30}$, bien conocidos por la Corona a través de relevantes personalidades castellanas que le avalaron ${ }^{31}$, Magallanes era la persona adecuada para guiar la expedición.

“A cambio, D. Carlos se comprometía a sufragar la expedición y a concederle una serie de ventajas y nombramientos, entre ellas la de nombrarlo capitán general de la Armada para lo que Magallanes debió rendirle pleito homenaje y servir siempre los intereses de la Corona de Castilla, algo que Magallanes cumplió fielmente hasta su muerte." 32

La Corona española implementa el proyecto, abandera la expedición y otorga importantes contrapartidas en términos de reconocimientos personales y generosas concesiones al ilustre marino. La Real Academia destaca que a cambio:

"El marino se comprometía particularmente a defender hasta la muerte el estandarte real que habría de enarbolar su buque o su capitana de flota, bajo pena de muerte y nota de infamia., ${ }^{, 3}$

hemisferio español." (COMELLAS GARCÍA-LLERA, JL, La primera vuelta al mundo, Rialp, Madrid, 2012, p. 32).

${ }^{29}$ FERNÁNDEZ-SHAW, C.M., Connotaciones españolas en el Pacífico austral. En INSTITUTO DE HISTORIA Y CULTURA NAVAL, XIII Jornadas de Historia Marítima: Álvaro de Mendaña: el Pacífico y su dimensión histórica. Cuadernos Monográficos del Instituto de Historia y Cultura Naval, n²6, Madrid, 1995, p. 48.

${ }^{30}$ Magallanes había participado en la conquista de Malaca en la expedición del rey Alburquerque, en 1511, (véase nota 11), y mantenido correspondencia con su amigo Francisco Serrano, que había alcanzado la isla de Ternate, (veáse nota 12). En la correspondencia Serrano le describe a su amigo Magallanes pormenorizadamente las diversas islas de la especiería, con todo lujo de detalles, distancias y localizaciones. Tales antecedentes, sin duda, resultarán muy relevantes en la negociación con la Corona.

${ }^{31}$ Nos referimos a los financiadores burgaleses, Cristóbal de Haro y, el Obispo de Burgos, Juan Rodríguez de Fonseca, a los que nos referiremos con más detalle en el $5^{\circ}$ epígrafe de este apartado.

\footnotetext{
${ }^{32}$ REAL ACADEMIA DE LA HISTORIA, idem, p. 2.

${ }^{33}$ Ibidem.
} 
Magallanes corresponde con un servicio y una lealtad a España que realmente es ejemplar, al ser asumido su compromiso hasta sus últimas y trágicas consecuencias personales. No podemos obviar que fallece en acto de servicio haciendo honor a la palabra dada a la Corona y a la nación que lo acoge. $\mathrm{Su}$ muerte al servicio de España es la evidencia final y máxima de su adscripción a nuestra nación.

\subsection{Sabotaje portugués a la expedición española}

Durante la preparación de la expedición lo que sí está contrastado son los diversos intentos del Rey de Portugal por frenar y boicotear la expedición española que abanderaba Magallanes, desde su misma génesis, desde su misma concepción, por los representantes portugueses en nuestra nación. A este respecto subraya la Real Academia de la Historia:

"Las cinco naves de la expedición se equiparon y aderezaron en Sevilla a pesar de los muchos inconvenientes que pusieron en todo momento tanto el embajador de Portugal, Alvaro Da Costa, como el factor en Andalucía del rey portugués D. Manuel, Sebastián Álvarez, quienes intentaron por todos los medios que el viaje no se realizara porque consideraban que se había entregado a una empresa española, por lo que lo calificaban como «renegado» $\mathrm{y}$ «traidor» a Magallanes, y como tal ha venido siendo considerado por buena parte de la historiografía portuguesa. ${ }^{, 34}$

No debe sorprender esta oposición de Portugal a la empresa española si tenemos en cuenta que era una expedición que previsiblemente podía restar protagonismo e iniciativa a la primera nación ibérica y europea en alcanzar las Indias por vía marítima.

La Ruta de la Seda, que también lo era de las especias, por tierra atravesaba Oriente Medio y había quedado interrumpida por el Imperio Otomano en 1453. Portugal había sido capaz de abrir una ruta comercial marítima gracias a que sus grandes marinos habían conseguido llegar a las Indias Orientales navegando en dirección Este, bordeando el continente africano: Bartolomé Díaz había doblado el Cabo de Buena Esperanza, en 1488, y Vasco de Gama, 10 años después, había conseguido alcanzar la India, el 4 mayo de 1498, al llegar a Calicut, en el estado indio de Kerala, estableciendo la denominada Ruta del Cabo. Portugal trataba por todos los medios de impedir la disputa de esa hegemonía marítima y comercial que ostentaba y que tanto había costado encontrar y asentar.

\footnotetext{
${ }^{34}$ Ibidem.
} 


\subsection{Respeto a la legalidad internacional establecida en Tordesillas.}

Al inicio de la Edad Moderna había intereses cruzados y motivos de disputa entre ambas naciones ibéricas; no podemos olvidar que, además de los intereses económicos por el monopolio del comercio de las especias por vía marítima, estaba en liza una disputa por la hegemonía política entre las dos grandes naciones peninsulares al inicio de la Edad Moderna.

En el trasfondo de la negociación resulta decisivo que Magallanes convence al Rey Carlos I de que las islas de la Especiería, a la que denominaban Maluco (las Molucas), pueden estar en territorios que quedarían bajo soberanía española de acuerdo con las jurisdicciones establecidas en el Tratado de Tordesillas ${ }^{35}$, que había sido suscrito con los portugueses en Valladolid, el 7 de junio de 1494, y por el que ambas naciones ibéricas delimitaron sus respectivos ámbitos de influencia geográfica para evitar confrontaciones entre dos naciones cristianas. Tal como recordaba el rey Felipe VI, en la conmemoración del acuerdo:

"Fue una epopeya sustentada en el Derecho y en el más estricto sentido de las justas relaciones internacionales desde los parámetros contemporáneos del siglo XVI. Una epopeya regulada en todos sus extremos, desde el respeto a las convenciones internacionales, el trato con los pueblos desconocidos, o el leal acuerdo pactado entre el poder político que apadrinaba la expedición y quienes habrían de ejecutarla." 36

El rey Carlos I era muy consciente de la importancia de respetar la legalidad internacional para evitar conflictos con los portugueses. De hecho, insiste en ella hasta el último momento, justo antes de partir la expedición, cuando le recuerda a Magallanes que este no le ha confirmado la distancia exacta y este le ofrece una respuesta basada en los cálculos de su amigo Serrano $^{37}$. No había mala voluntad en lo reportado. Acaso hay que destacar a este respecto que los cálculos técnicos que se barajaban sobre la esfericidad

${ }^{35}$ El Tratado de Tordesillas (1494), suscrito por los Reyes Católicos, Isabel I de Castilla y Fernando II de Aragón con Juan II de Portugal, constituyó la referencia fundamental de legalidad internacional de la época, al delimitar los ámbitos de potestad territorial e influencia y navegación de las naciones ibéricas hasta una línea imaginaria que distaba 370 leguas de las Islas portuguesas de Cabo Verde. El Tratado de Tordesillas tuvo vigencia durante todo el siglo XVI, y posteriormente, hasta el Tratado de Madrid de 1750. Incluso fue restaurado, durante un tiempo, por el Tratado del Prado (1761). Definitivamente se abandonó tras el Tratado de San Ildefonso (1777). El Tratado está declarado Patrimonio de la Humanidad por la UNESCO (2007).

${ }^{36}$ FELIPE VI, Palabras de su Majestad El Rey con motivo de la conmemoración de las Capitulaciones de Valladolid. Monasterio de Nuestra Señora de Prado. Valladolid, 22 de marzo 2018. Disponible en:

http://www.casareal.es/GL/Actividades/Paginas/actividades_discursos_detalle.aspx?data=6018

${ }^{37}$ COMELLAS GARCÍA-LLERA, JL, La primera vuelta al mundo, Rialp, Madrid, 2012, p. 50. 
de la Tierra eran vagos y erróneos, porque sabemos que suponían una dimensión de la Tierra mucho menor de la real. Esta circunstancia tenía consecuencias también políticas y en las relaciones bilaterales, porque el desconocimiento de la dimensión real de la Tierra impedía realmente determinar con exactitud los grados de cada meridiano, con lo cual el Tratado podía ser interpretado de forma distinta por los navegantes de ambas naciones, como de hecho lo fue. Luego la disputa no era arbitraria, un mero conflicto de intereses, sino que tenía un fundamento legítimo in re.

\subsection{Financiación española de la empresa}

En cuanto a la financiación de la expedición, dados los altos costes de la misma, la Academia destaca la solución de la contribución mixta:

"El coste de la expedición estuvo sufragada de la siguiente manera: un $75 \%$ por la Corona castellana y el otro $25 \%$ por un grupo de comerciantes burgaleses entre los que destaca Cristóbal de Haro, importante mercader en el comercio de las especias." 38

Cristóbal de Haro, era un empresario burgalés, probablemente de origen judío, que se había enriquecido con el comercio de la lana castellana hacia Flandes y había establecido una tupida red de relaciones con otras notables familias de comerciantes centro-europeos, muchas de ellas judías. De hecho, el comerciante burgalés estaba casado con una mujer flamenca, hecho que, en aquella época, además de inusual y llamativo, resultaba indicativo del tipo de relaciones y conexiones que tenía establecidas. Los Haro, aunque asentados en Burgos, de hecho, contaban con representación comercial en todas las grandes ciudades comerciales de la Europa Occidental.

Las grandes familias de comerciantes centro-europeos colaboraban con la Corona y jugaban un papel muy destacado en la financiación de sus proyectos. Cabe recordar que, en el caso concreto de Carlos I, en su elección como emperador del Sacro Imperio Romano Germánico, intervinieron los Fúcar, una poderosa familia alemana que financió el costoso proceso que le condujo a ser nombrado emperador.

Este tipo de financiación mixta, precedente mutatis mutandi de la actual colaboración público-privada, tenía antecedentes relevantes, y además exitosos, en la propia Corona Española, en particular en la financiación de la empresa que condujo al descubrimiento de América, encabezada por Cristóbal Colón, y que

\footnotetext{
${ }^{38}$ REAL ACADEMIA DE LA HISTORIA, idem, p. 2
} 
fue financiada, además de por la propia Reina Isabel I de Castilla, por el empresario valenciano Luis de Santángel Vilamarxant. Fue este comerciante el que consiguió que los Reyes Católicos volvieran a escuchar la propuesta de Colón en segunda instancia y accediesen a sus pretenciosas exigencias, reunión en la que el mismo Santángel se ofreció a colaborar en la financiación, lo cual parece que resultó decisivo para la definitiva implicación de la Corona en el proyecto.

En el caso de Cristóbal de Haro, había colaborado también con los portugueses en una etapa previa en que estos ofrecieron posibilidades de participación comercial en sus territorios de ultramar a hombres de negocios extranjeros, lo que motivó que numerosos comerciantes castellanos se trasladasen a Portugal. Cristóbal de Haro, de hecho, se desplazó a Lisboa en 1480 y colaboró en diversas expediciones lusas, como las que condujeron a la exploración del Río de la Plata, que, por la anchura del estuario, confundieron con un paso interoceánico. Cristóbal permaneció en Portugal durante 37 años y colaboró desde allí con las citadas familias europeas de los Fúcar y los Bélzar. Esta etapa es muy importante, decisiva, para la configuración financiera de la expedición española. Tal como ha subrayado la geógrafa e historiadora canadiense Huxley Barkham, experta en historia marítima:

"However, it appears that the most profitable acquaintanceship that Cristóbal made in Lisbon was with Fernando de Magallanes -Magellan, as we call him. When Magellan left Portugal for Spain in 1517, it is clear that Cristóbal de Haro took a considerable interest in him and in his project. Haro became one of the principal investors, along with the Bishop of Burgos, Juan Rodríguez de Fonseca, in the voyage that set out from Seville in 1519 and made the first circumnavigation of the globe." 39

Cuando los portugueses cambiaron su política y desincentivaron la participación de extranjeros en la financiación de sus empresas, Cristóbal de Haro volvió a centrar su actividad e intereses en España. El comerciante burgalés ya había conocido en Lisboa a Magallanes y se había interesado por su proyecto, por lo que, cuando el marino se muda a España en 1517, el comerciante burgalés le sigue la pista y se interesa por participar en la financiación del viaje. Lo que finalmente hará, junto al Obispo de Burgos, Juan Rodríguez de Fonseca ${ }^{40}$.

${ }^{39}$ HUXLEY BARKHAM, S., «The Mentality of the men behind the sixteenth-century Spanish Voyage to Terranova». En WARKENTIN, G.; PODRUCHNY, C. Decentring the Renaissance: Canada and Europe in Multidisciplinary Perspective, 1500-1700. University of Toronto Press, Toronto, 2001, p. 115

${ }^{40}$ Eclesiástico humanista, científico y mecenas, proveniente de una ilustre familia castellana, que ejerció funciones diplomáticas para los Reyes Católicos y colaboró con ellos en la organiza- 
La participación de la financiación privada, con el respaldo de personalidades tan relevantes y buenas conocedoras de los antecedentes del proyecto, seguramente fue percibida por la Corona española como una importante garantía adicional. De ahí el respaldo al proyecto y el beneplácito final a la expedición.

La implicación de la Corona española, no se limitó a la financiación, sino que se hizo visible también en el cuadro de mandos que capitaneaban las diversas naves y los oficiales que conformaron la expedición. Tal como subraya la RAH:

"Carlos I nombró capitán de otras naves a destacados castellanos de su confianza, como Juan de Cartagena, capitán de la nao San Antonio o la Concepción, que capitaneaba Gaspar de Quesada." ${ }^{, 1}$

La Corona coloca así a personas de su confianza en los puestos clave de la misma, en parte para asegurar la lealtad a la Corona, pero en parte también para garantizarse el cumplimiento de los fines previstos.

Para la organización de la expedición se dispuso una armada compuesta por 5 naves, todas ellas con nombres religiosos: Trinidad (Magallanes), San Antonio (Juan de Cartagena), Concepción (Gaspar de Quesada), Santiago (Juan Serrano) y Victoria (Luis de Mendoza).

La travesía solo sería completada por la nao Victoria, finalmente capitaneada por Juan Sebastian Elcano. Se trataba de una nave construida en los astilleros de Zarautz (País Vasco), aunque su bautismo fue realmente andaluz. Su nombre hace honor a Santa María de la Victoria de Triana, en Sevi1la, donde Magallanes juró servir a Carlos I. Construcción vasca, financiación burgalesa, implementación sevillana... Cabe apreciar aquí la colaboración entre las distintas zonas de España en una empresa colectiva que suponía todo un desafío en todos los sentidos: técnico, logístico, náutico, humano y espiritual. Solo el aprovisionamiento de la expedición supuso tanto dinero como el coste de las 5 naves:

"Está documentado el costo del avituallamiento de las cinco navíos y los 234 tripulantes para dos años de navegación: en total 1.252.909 maravedíes, casi tanto como el costo total de los cinco buques"42

ción de la política castellana en América, obteniendo numeroso cargos y altas responsabilidades derivadas de su servicio a la Corona.

${ }^{41}$ REAL ACADEMIA DE LA HISTORIA, idem, p. 2

${ }^{42}$ HIGUERAS RODRÍGUEZ, MD., La dieta de vuelta al mundo. Alimentos básicos a bordo en el siglo XVI, en volumen monográfico «El viaje de los alimentos. Expediciones, descubrimientos y conquistas que produjeron el intercambio de alimentos entre distintos continentes», 
Como se aprecia por el coste del avituallamiento, que equivalía casi al coste de las naves, ya anticipaban, al menos hasta cierto punto, la larga travesía que les esperaba.

\section{CRÓNICA DE LA PRIMERA CiRCUNNAVEGACIÓN DE LA TIERRA}

\subsection{Partida desde Sevilla el 10 de agosto de 1519.}

El primer hecho significativo en la cronología de la expedición, una vez referenciados los antecedentes, la negociación y los intereses en liza con Portugal, acaso sea el de su partida, que la RAH refiere en los siguientes términos:

"La flota partió de Sevilla el día 10 de Agosto de 1519 hacia Sanlúcar, donde se incorporó Magallanes después de hacer testamento en el Alcázar de Sevilla, donde había vivido los dos años anteriores."

El 10 de agosto parte finalmente la expedición compuesta por cinco naves y un total de 239 hombres $^{44}$, entre oficiales, tropa y marinería. Magallanes se incorpora a su paso por Sanlúcar de Barrameda, asume el mando, y tras unos días de avituallamiento y de preparativos finales en que va y vuelve a tierra, y tras testamentar, finalmente se hacen a la mar y se adentran en el Océano Atlántico en dirección sur.

La primera escala tendrá lugar en Tenerife, en las Islas Canarias, para continuar navegando hacia el sur, pasando frente a las costas de África a la altura de Senegal, a las que se aproximan para evitar las Islas de Cabo Verde que pertenecían a Portugal.

A la altura de Guinea y Sierra Leona ya toman rumbo marcadamente sudoeste y se adentran en la travesía oceánica, donde sufrirán tempestades y presenciarán fenómenos metero-ígneos como el Fuego de San Telmo ${ }^{45}$. Los marineros interpretan el resplandor luminoso del fenómeno atmosférico que ilumina las naves como una señal de protección divina, aunque la intensidad que alcanza la radiación les ciega durante horas.

Sociedad Geográfica Española, $n^{\circ}$ 62, enero-abril, 2019, p. 37. Respecto al número de expedicionarios ya se ha señalado que hay leves discrepancias, según las fuentes.

${ }^{43}$ REAL ACADEMIA DE LA HISTORIA, idem, p. 3

${ }^{44}$ Algunas fuentes (Fernández Navarrete) sitúan el número inicial de expedicionarios en 265. El dato de 239 que nosotros reflejamos lo tomamos de V Centenario de la I Vuelta al Mundo, disponible en http://vcentenario.es/

${ }^{45}$ Fenómeno metero-ígneo que genera una corona electroluminiscente por efecto de la ionización de las masas de aire, se genera por un elevado diferencial de potencial eléctrico en la atmósfera y suele estar asociado a fuertes tormentas eléctricas. El proceso eléctrico genera un resplandor visible de color blanco-azulado. 
En la travesía oceánica Juan de Cartagena será relevado del mando de la nao San Antonio por arrogarse potestades indebidas y saludar incorrectamente a Magallanes.

A los cuatro meses de su partida de España, la flota arribará a las costas americanas. El 13 de diciembre de 1419 llegan a las costas brasileñas en la zona de Río de Janeiro. Continúan bordeando la costa americana en dirección sur y comienzan a buscar un paso hacia el entonces denominado Mar del Sur. Lo creen encontrar en el amplio estuario que forma el Río de la Plata, en su desembocadura, en la actual frontera entre Uruguay y Argentina, pero tras 15 días de navegación infructuosa por la zona se dan cuenta de que realmente no tiene salida. Se trata de un gran estuario, de hecho, es el mayor del mundo, pero no el canal que desesperadamente buscan en una región desconocida. ${ }^{46}$

\subsection{Descubrimiento del Estrecho de Magallanes}

Uno de los objetivos principales de la expedición consistía en encontrar ese paso desde Océano Atlántico hacia el Mar del Sur, al que ellos rebautizarían como Pacífico. No había evidencia de su existencia. De hecho, ya había sido buscado, antes que ellos, por los portugueses en el estuario del Río de la Plata, y todavía antes, por los españoles, por Juan Díaz de Solís, que a finales de 1515 inspeccionó la zona y en enero de 1516 descubrió el amplio estuario de agua dulce. Antonio Pigafetta, cronista no oficial de la expedición, alude a estas tentativas precedentes:

"Anteriormente se había creído que esa agua no era la de un río sino un canal por el cual se pasaba al Mar del Sur; pero se vio bien pronto que no era sino un río que tiene diecisiete leguas de ancho en su desembocadura." ${ }^{, 47}$

La expedición siguió navegando hacia el sur. El 31 de marzo de 1520, encontrándose ya a escasas jornadas de la Antártida y sin haber localizado aún el paso, Magallanes hubo de limitar las raciones de comida a la espera de poder hallarlo. Las duras condiciones climáticas, las tempestades, el intenso frío y el racionamiento, sumados a la no evidencia de su existencia,

\footnotetext{
${ }^{46}$ Comellas pone de relieve el hecho de que, según se dirigen hacia el sur, se adentran en un escenario absolutamente desconocido, porque: "Al estuario del Plata habían llegado Juan Díaz de Solís. Posiblemente también Sebastián Caboto y Américo Vespucci, ambos al servicio de España. Pero al Sur de Punta Piedras no había navegado jamás barco de vela alguno, ni español, ni europeo ni ninguna otra parte del mundo." (COMELLAS GARCÍA-LLERA, JL, La primera vuelta al mundo, Rialp, Madrid, 2012, p. 64).

${ }^{47}$ PIGAFETTA, A., Primer viaje alrededor del globo. La crónica en vivo de la expedición de Magallanes-Elcano 1519-1522, Civiliter, Sevilla, 2012, p. 19
} 
hicieron cundir el desánimo y provocaron que finalmente algunos capitanes y oficiales se sublevasen en un episodio que se conoce como la rebelión del Puerto de San Julián.

Los capitanes Gaspar de Quesada y Luis de Mendoza, junto con Antonio de Coca y Juan de Cartagena, se amotinaron contra el almirante de la flota por desacuerdo con el mando. También Juan Sebastián Elcano figuró entre los que se amotinaron, si bien, como apunta Comellas, que califica el amotinamiento como sedición 48 " "no tuvo una participación directa en los hechos"49.

La insurrección fue reprimida por Magallanes con la muerte de Mendoza, capitán de la nao Victoria. Además condenó a muerte a Quesada, que fue ejecutado, y desterró en aquellas gélidas tierras a Juan de Cartagena y al clérigo Pedro Sánchez de la Reina. Al resto los indultó por ser necesarios para la continuidad de la expedición. ${ }^{50}$

La situación se agravó aún más cuando el 3 de mayo, inspeccionando las costas de la zona de San Julián, la nave Santiago se estrelló contra unas rocas en la desembocadura del río Santa Cruz, quedando impracticable. Su tripulación hubo de ser realojada en las otras naves y el mando reorganizado. Juan Serrano fue puesto al mando de la Concepción y Duarte Barbosa de la Victoria.

En octubre de 1520 la San Antonio, tras explorar una bahía que todavía hoy se llama Bahía Inútil, y tras no lograr contactar con las otras naves, finalmente, desertó de la expedición y regresó a Sevilla.

En medio de la contrariedad y la desolación, el ansiado paso interoceánico, un estrecho canal que comunica el Océano Atlántico con el Pacífico finalmente fue localizado en la región más austral de Chile. Magallanes 1o denominó De Todos los Santos porque fue hallado el 1 de noviembre de 1520, festividad de todos los santos según el santoral de la Iglesia Católica. La tripulación respiró aliviada.

\footnotetext{
${ }^{48}$ La sedición, como es sabido, supone un alzamiento público y tumultuario contra la autoridad, el orden público o la autoridad militar, pero sin alcanzar la gravedad ni de la rebelión ni de la traición. Colón o los hermanos Pinzón, en el caso de España, o Francis Drake, en el mismo s. XVI, y Cook, ya en el siglo XVIII, también las sufrieron, como bien recoge Comellas. Era un delito muy común en las largas travesías marítimas debido a las duras condiciones de la navegación y la vida a bordo, la amplia duración de las travesías y la incertidumbre de las rutas.

${ }^{49}$ COMELLAS GARCÍA-LLERA, JL, Idem, p. 75.

${ }^{50}$ Comellas se refiere al mismo de la siguiente forma: "Fue uno de los acontecimientos más dramáticos de aquellos enloquecedores tres años, y para algunos de sus protagonistas habría de terminar trágicamente. También se le puede considerar un paréntesis triste, nada heroico por demás, en que se manifestaron algunas de las debilidades de la naturaleza humana, la desconfianza, la doblez, la traición, la crueldad. Los héroes tienen defectos como todos los seres humanos, y en este sentido la rebelión del Puerto de San Julián es uno de los ejemplos de que los protagonistas de la primera vuelta al mundo, a pesar de su decisión, de su capacidad de sufrimiento, de su arrojo casi sobrehumano, demostraron ser hombres al fin y al cabo." (COMELLAS GARCÍALLERA, JL, La primera vuelta al mundo, Rialp, Madrid, 2012, pp. 71 -72).
} 
El enclave se trata de un estrecho canal natural en una región cuajada de islas e islotes, que forman un auténtico laberinto, en una zona de corrientes cambiantes, fuerte oleaje y obstáculos que hacen muy compleja y arriesgada la navegación. La gran aglomeración de islas todavía hace más complicada la navegación si tenemos en cuenta que se realizaba a vela, como apunta Comellas. ${ }^{51}$

Este importante hallazgo cartográfico para la navegación náutica en la región más austral del planeta suponía la culminación de uno de los objetivos principales de la expedición. La RAH lo destaca sin omitir las dificultades que supuso y la situación de desesperanza y contrariedad en que se hallaba la tripulación:

"Fernando de Magallanes, tras una serie de contratiempos y motines entre la tripulación, logró encontrar el paso al Océano Pacífico por el Estrecho que lleva su nombre y una vez cruzado este océano, con solo tres navíos, murió en Mactán, una isla del archipiélago de las Filipinas., ${ }^{52}$

Podemos suponer el alivio que sentiría la expedición al encontrar ese estrecho paso que hoy lleva el nombre de Magallanes. Al mar que le precede, según el sentido de navegación de la expedición, lo denominó el mismo marino De las Once mil Vírgenes, por ser el día de Santa Úrsula, de nuevo un nombre religioso acorde al santoral católico, tal como refiere Alonso Cabellos: "al ser esa la fecha en que la Iglesia las consagraba"53. El cabo atlántico principal, que da acceso al Estrecho, todavía conserva el nombre asignado por el capitán de la expedición española ${ }^{54}$.

\subsection{Bautismo del Mar del Sur como Pacífico por condiciones meteorológicas inusuales.}

El tercer hecho significativo es que una vez cumplido este objetivo cartográfico y náutico, de localización del estrecho, se adentran en el -hasta entonces- deno-

${ }^{51}$ COMELLAS GARCÍA-LLERA, JL, Idem, p. 100. Por ello añade Comellas, que solo navegaban de día, permaneciendo anclados durante la noche, en una época del año en que "las noches solo duran solo 4 ó 5 horas y los días casi 20.” (Ibidem).

52 REAL ACADEMIA DE LA HISTORIA, idem, p. 3

${ }^{53}$ ALONSO CABELlOS, A., Magallanes y Elcano: Primus circumdediste me, Sevilla, 2016, p. 209.

${ }^{54}$ En la actualidad se denomina de forma abreviada Cabo De las Virgenes o, directamente, en su forma más usual, Cabo Virgenes. Con coordenadas: 52 $19^{\prime} 59.88^{\prime \prime} \mathrm{S}, 68^{\circ} 21^{\prime} 0^{\prime \prime} \mathrm{W}$ (Fuente: GeoHack. Disponible en:

https://tools.wmflabs.org/geohack/geohack.php?language=es\&pagename $=$ Cabo_V\%C3\%ADrgen es\&params=-52.3333_N_-68.35_E_type:landmark).

Se ha considerado el punto biooceánico de contacto entre el océano Atlántico y el Estrecho de Magallanes durante casi todo el siglo XX, aunque en la actualidad Chile y Argentina han acordado situarlo en la Punta Dungeness, ya dentro del estrecho. 
minado Mar del Sur y del que constatan que realmente se trata, por su dimensión, de un océano. De hecho, el Pacífico es, por su extensión, el mayor océano del mundo. Como es sabido, había sido descubierto por Vasco Núñez de Balboa, en 1513, tras cruzar Panamá por tierra, aunque el explorador de Jerez de los Caballeros tomó posesión del mismo para la Corona de España pensando que se trataba de un mar. Por ello lo bautizó como Mar del Sur.

Por ello, recordaba el geógrafo O.H.K Spate, exdirector de la Escuela de Investigación en Estudios sobre el Pacífico de Australia, citando a Christopher Marlowe $^{55}$ :

"Strictly speaking, there was no such a thing as the Pacific until in 1520 I Fernao de Magalhais, better known as Magellan traversed the huge expanse of waters, which then received its name."

Magallanes no fue enviado al océano Pacífico porque, en rigor, antes de la expedición, no se tenía constancia de la existencia del Pacífico como un océano, sino como un mar, del que se desconocía su extensión, su topografía y su navegación. Dada la calma que los marinos españoles encontraron al aventurarse en sus aguas lo rebautizaron como Pacifico.

Si a alguien le sorprende el nombre de Pacifico asignado al mayor océano del mundo, que suele tener frecuentes tempestades, con tifones, huracanes y una subyacente actividad sísmica que ocasiona incluso maremotos, con destructivos tsunamis, conviene recordar y subrayar las excepcionales condiciones climatológicas que concurrieron en esas fechas e hicieron posible la inusual calma que los expedicionarios españoles encontraron en esa región.

Al parecer, está constado que, en aquel año de 1521 en que la expedición se adentró en el océano Pacífico, se dieron dos fenómenos de «El Niño» ${ }^{56}$ seguidos, dos eventos climatológicos excepcionales, de forma consecutiva. Un factor climatológico durante mucho tiempo desconocido, y no considerado por la historiografía, como bien apunta José Luis Comellas, en la introducción a su relevante estudio, un fenómeno que debe su nombre al nacimiento del Niño Jesús, porque generalmente se inicia en Navidades $^{57}$. Acaso fue una muestra de la acción de la Providencia en la que los navegantes tanto confiaban.

${ }^{55}$ MARLOWE, C., The First Part of Tamburlaine the Great, 1590, IV. Iv, tomado de SPATE, O.H.K., The Spanish Lake, (original, 1979), The Australian National University, Camberra, 2004, p. 1

${ }^{56}$ Fenómeno climatológico también conocido como Oscilación del Sur ó ENSO (por sus siglas en inglés: El Niño Southern Oscilation). Se trata de una variación climática temporal, un patrón climático cíclico, pero no periódico, no regular, que hace que las aguas superficiales del Océano Pacífico sean más cálidas y tranquilas de lo habitual.

${ }^{57}$ COMELLAS GARCÍA-LLERA, JL, La primera vuelta al mundo, Rialp, Madrid, 2012, 
Entre las muchas anécdotas del viaje, en la travesía del Pacífico, es de reseñar que, encontrándose gravemente enfermo Juan Sebastián Elcano, decidió hacer testamento en medio del Pacífico, al que todavía denomina mar. En su testamento el marino afirma:

"En la nao Vitoria en el mar Pacífico, á un grado de la línea equinoccial á veinte é seis días del mes de julio año del Señor de mil é quinientos é veinte é seis, en presencia de mí Iñigo Ortés de Perea contador de la dicha nao Capitana por sus Majestades, el capitan Juan Sebastian del Cano vecino de Guetaria, estando enfermo en la cama de su cuerpo, é sano de su juicio é entendimiento natural, tal cual nuestro Señor plugo de le dar, temiéndose de la muerte ques cosa natural, estando presentes los testigos infrascriptos, presentó esta escriptura cerrada y sellada que dijo ser su testamento y última voluntad, el cual dijo que otorgaba é otorgó por su postrimera é última voluntad, é mandaba é mandó que se guardase é cumpliese é efectuase todo lo que en él contenido é cada una cosa é parte de ellos."

A continuación, se cita a todos los testigos que estaban presentes: Martín García Carguizano, Andrés de Gorostiaga, Martín de Uriarte, Joanes Zabala, Hernando de Guevara, Andrés Aleche, Andrés de Urdaneta, todos los cuales firmaron el testamento en medio de la travesía del Pacífico.

"In Dei nomime amen. Sepan cuantos esta carta de testamento vieren que yo el capitan Juan Sebastian del Cano vecino de la villa de Guetaria, estando enfermo persona, é sano de mi entendimiento é juicio natural, tal cual Dios nuestro Señor me quiso dar, é sabiendo que la vida del hombre es mortal, é la muerte muy é la hora muy incierta, é para ello cualquier católico cristiano ha de estar aparejado como fiel cristiano para cuando fuese la voluntad de Dios; porende yo creyendo firmemente todo lo que la Santa madre iglesia cree fue verdaderamente, ordeno é fago mi testamento é postrimera voluntad en la forma siguiente:

\footnotetext{
p. 8. El propio historiador aclara que "Realmente, El Niño no es un fenómeno de hoy, porque se ha operado, según los paleoclimatólogos, desde hace mucho tiempo, tal vez desde hace milenios. El nombre se lo pusieron los pescadores peruanos tal vez desde hace ciento cincuenta años, porque se inicia con las Navidades, es decir, con las fiestas del Niño Jesús." (Ibidem, pp. 106-107). Comellas recoge la excepcionalidad de esa sucesión de fenómenos cíclicos, que no suele darse de forma consecutiva, y sobre el que, sin embargo, apunta el historiador: "se sabe que en los cambios de año 1519-1520 y 1520-21 se registraron dos episodios consecutivos de El Niño" (Ibidem, p. 108).

${ }^{58}$ Testamento de Juan Sebastián Elcano, copiado del original que existe en el Archivo General de Indias en Sevilla, remitido autorizado por el archivero D. Jose de la Higuera Lara, tomado de FERNÁNDEZ NAVARRETE, M., SALVÁ, M. y SAINZ DE BARANDA, P. (Miembros de la Academia de Historia), Colección de documentos inéditos para la historia de España. Vol. I: Documentos relativos a Juan Sebastián del Cano, De la Viuda, Madrid, 1942, p. 252-253. (Reproducido con los errores ortográficos y erratas del documento original).
} 
Primeramente mando mi ánima á Dios que la crió é me redimió por su preciosa sangre en la Santa cruz é ruego é suplico á su bendita madre Señora Santa María, nuestra Señora, que ella sea mi abogada delante de su precioso hijo, que me quiera alcanzar perdón de mis pecados é me lleve á su gloria santa., ${ }^{, 59}$

Elcano dispone ser enterrado en la villa de Guetaria, en la Iglesia del Salvador, donde descansan los restos de su padre y sus antepasados y a la que dispone le sean donados seis ducados de oro, y otros tantos a la Iglesia de San Martín, y sigue haciendo donativos a otras iglesias y santuarios de la Virgen: a la de San Prudencio, a la de la Magdalena, a los pobres de San Lázaro, a la Iglesia de San Antón, a la de San Pedro, etc.

Sobre la travesía por el Pacífico, es de reseñar que fue mucho más larga de lo que habían estimado. Los cálculos sobre la dimensión de la Tierra de la época suponían un tamaño mucho menor de la esfera terráquea, en consecuencia, la travesía por el desconocido e inexplorado océano resultó considerablemente más larga de todas las posibles estimaciones y la incertidumbre mucho mayor de lo imaginable.

De hecho, navegaron por el Pacífico durante unos 4 meses sin tocar contacto con tierra firme, lo cual equivalía a recorrer toda la extensión del mundo conocido hasta entonces. ${ }^{60}$ Añádase a ello el desconocimiento de la travesía, la ubicación y la posición exacta en que se encontraban, para apercibirse de la incertidumbre que soportaron durante la travesía.

De hecho, la primera tierra firme que se encuentran, tras más de 100 días de navegación por el desconocido océano y en condiciones extremas, son las islas de Guam, cerca de la región de las Marianas, donde además no son bien recibidos. Así lo refiere Pigaffeta:

"Quiso el comandante en jefe detenerse en la más grande para tomar refrescos y provisiones; pero esto no nos fue posible porque los isleños venían a bordo y se robaban ya una cosa ya otra, sin que nos fuese posible evitarlo." ${ }^{, 61}$

De hecho, las denominan Islas de los Ladrones ${ }^{62}$, porque sus habitantes les intentan robar todo lo que llevaban, hasta el esquife de la Trinidad, que tuvieron que acudir a tierra para recuperarlo.

\footnotetext{
${ }^{59}$ Ibidem, pp. 253-254. (Reproducido con los errores ortográficos y erratas del documento original).

60 Dato náutico tomado de V Centenario de la I Vuelta al Mundo, disponible en http://vcentenario.es/ Como es sabido, el Océano Pacífico es el mayor de los 5 océanos del planeta, con una longitud (norte-sur) de $15.000 \mathrm{Km} \mathrm{y}$ una anchura (este-oeste) de casi $20.000 \mathrm{Km}$, cubriendo un área total de $155.557 .000 \mathrm{~km}^{2}$, la cual supone $1 / 3$ de la dimensión total de la superficie de la Tierra.

${ }^{61}$ PIGAFETTA, A., Idem, p. 38.

${ }^{62}$ Ibidem, p. 40.
} 
Mejor suerte y recibimiento tienen en Filipinas. Son los primeros europeos que contemplan estas islas en las antípodas del globo y a las que Magallanes bautiza como Islas de San Lázaro. En Filipinas los españoles ponen especial interés en dispensarles un buen trato para incorporar estas islas a la soberanía española. Los españoles llevan a un nativo que les hace de intérprete, lo cual facilita mucho el entendimiento y las buenas relaciones.

También son bien recibidos en Massana (Limassawa), a donde llegan el 25 de marzo de 1521, donde los españoles también consiguen establecer una buena relación con los isleños e incluso celebrar una misa con ellos en la festividad del Domingo de Pascua. Después realizan numerosos bautismos y una evangelización de los nativos, comenzando por los jefes, que se muestran interesados y receptivos a la enseñanzas cristianas. ${ }^{63}$

El 7 de abril de 1521 llegan a Zubú (Cebú), donde también podrán disfrutar de una estancia pacífica y una convivencia tranquila con los nativos, gracias a que Magallanes y el rey Zubú intercambian regalos y traban buenas relaciones. El capitán de la expedición española les ofrece la protección de la Corona de Castilla y la conversión a la fe cristiana que los españoles profesan y portan. También los nativos se muestran receptivos a la fe y se realizan nuevas conversiones y bautismos. ${ }^{64}$

\subsection{Muerte de Fernando de Magallanes, en Mactán, en 1521.}

El 16 de marzo de 1521 llegaron a Samar, una isla cercana a Cebú. A su llegada los españoles descubren que los indígenas de las distintas islas son diferentes como lo es su recibimiento y su hospitalidad hacia la expedición. Pese a que los españoles tratan de confraternizar y relacionarse pacíficamente con todas las tribus locales, no son bien recibidos por el jefe Cilapulapu, que no acepta al monarca al que los españoles representan, ni acepta su protección, ni le quieren ofrecer tributos, ni siquiera hospitalidad. Al final, se ven abocados a un enfrentamiento con el que Magallanes piensa que les puede someter.

Pese a la inferioridad numérica de los españoles, Magallanes está convencido de poder derrotar a los nativos sin grandes dificultades. Tan seguro está de la victoria que no solicita la ayuda de las restantes naves españolas. Así, el 27 de abril encabeza a un grupo de unos 50 españoles que se enfrentan a más de 1.000 guerreros del clan de Cilapulapu, en las playas de Mactán. No están claras las razones de la derrota española. Se baraja que la marea baja obligó a los españo-

\footnotetext{
${ }^{63}$ Ibidem.

${ }^{64}$ Ibidem.
} 
les a dejar los barcos muy lejos de la costa y a tener que prescindir de los cañones, su principal arma pesada, por no poder desembarcarlos. Ello, unido a la distancia de $1 \mathrm{~km}$, que los hombres tuvieron que recorrer, desde la zona de desembarco hasta el lugar del enfrentamiento, caminando por el agua y armados, pudo hacer que llegasen agotados al enfrentamiento. Ya en el combate, la distancia a las naves también dificultaría el reaprovisionamiento de municiones, y en el desenlace final, en el combate cuerpo a cuerpo, el propio Magallanes fue alcanzado por una lanza, cayendo herido al suelo. Una vez caído el jefe de la expedición española fue lanceado por los nativos.

Magallanes fallecía así a escasas jornadas de alcanzar la isla de la Especiería. Su sucesor, Duarte Barbosa, cuñado del propio capitán, moría también poco después, junto a otros 30 españoles, al verse sorprendidos en una trampa en la isla de Cebú. A toda prisa la expedición hubo de partir y alejarse apresuradamente de Cebú.

En esos momentos, quedaban 115 hombres de los 239 que partieron de Sevilla, solo dos años antes, y ya solo disponen de 3 de los 5 navíos de la expedición. Es decir, ha fallecido más de un $50 \%$ de los miembros de la expedición, además del promotor de la misma.

En la isla de Bohol deciden quemar la Concepción, que era la que se encontraba en peor estado de las naves restantes y reubican a los hombres en las dos naos restantes ${ }^{65}$. Con lo cual ya solo les quedan 2 naves. Podemos hacernos una idea de en qué situación de desesperanza se encontraría el centenar de supervivientes. En tales circunstancias extremas, en las antípodas del globo, la expedición hubo de reorganizarse para continuar la ruta. Tal como refiere la RAH:

"Después de la desaparición de Magallanes, se hicieron cargo de los dos navíos que quedaban una vez que llegaron a las Molucas, Juan Sebastián Elcano de la Victoria y Gonzalo Gómez de Espinosa de la Trinidad."66

El mando de la expedición lo asumió en primera instancia Gonzalo Gómez de Espinosa, mientras Juan Sebastián quedaba al mando de la nao Victoria.

Tras la estancia en Bohol, harán escala en Butuán, donde son bien recibidos y donde pueden reavituallarse. Buscando la isla de Maluco (Molucas) hacen escala en otras islas de la región: Palawan, en junio de 1521, Cavite, en octubre, Burne (Borneo), el 9 de octubre de 1521. Deambulan por una serie de islas, hasta que deciden tomar por la fuerza a dos guías que les conduzcan hasta ellas.

\footnotetext{
${ }^{65}$ Ibidem.

${ }^{66}$ REAL ACADEMIA DE LA HISTORIA, idem, p. 3
} 


\subsection{Asunción del mando por Juan Sebastián Elcano}

El 6 de noviembre de 1521 por fin llegan a la isla de Maluco (Molucas), la tierra donde crece el jengibre, la canela, el clavo, las preciadas especias que condimentan, preservan y realzan el sabor de los alimentos y que eran valoradas y buscadas como el oro en aquel tiempo. A continuación las dos naves, Trinidad y Victoria parten y se dirigen hacia Tidore (Todore), la mayor isla de la Especiería en la región de las Molucas, la cual alcanzan el 8 de noviembre de 1521. Tal como refiere la RAH:

"Después de cargados los navíos, pusieron rumbo a Tidore, desde donde Elcano a bordo de la Victoria partió para el viaje de vuelta, decidiendo hacerlo por el Cabo de Buena Esperanza, y Gómez de Espinosa, que pensaba volver por la ruta contraria, tuvo que detenerse a reparar la Trinidad. ${ }^{, 67}$

Cargaron sobre todo clavo, porque, tal como apunta Comellas, "el clavo tiene sobre otras especias una ventaja clara: es la de que, a igualdad de peso, ocupa menos espacio"68. Por lo que permanecen una semana cargando las naves, e inclusive dejan una parte de la carga en tierra para ser recogida en una futura expedición. Alcanzado el objetivo en las islas de la Especiería y bien cargadas las naves, el 8 de diciembre, ambas naos parten con rumbo sur, rodeadas por "una flotilla de piraguas, que deseaban prolongar la despedida". ${ }^{9}$

Posteriormente ambas naves hubieron de separarse porque la Trinidad hacía agua y debía ser reparada antes de proseguir la navegación. En ese momento, la última nave, la Victoria, capitaneada por Juan Sebastián Elcano, decide retornar por Oriente, para tratar de completar el objetivo no menos complejo de conseguir retornar con el preciado cargamento, completando la circunnavegación del globo. No era una empresa nada fácil, ni exenta de muchos y nuevos peligros para la expedición española:

"Según los cronistas, el viaje de vuelta por el Índico, huyendo de los portugueses e intentando no aproximarse a sus enclaves, fue el más peligroso de toda la inmensa travesía, tanto por los fenómenos naturales como por la necesidad de evitar las aguas portuguesas." ${ }^{, 70}$

\footnotetext{
${ }^{67}$ Ibidem.

${ }^{68}$ COMELLAS GARCÍA-LLERA, JL, La primera vuelta al mundo, Rialp, Madrid, 2012,

${ }^{69}$ Ibidem.

${ }^{70}$ Ibidem.
} p. 147. 
En la isla de Burú, en diciembre de 1521, realizan el penúltimo repostaje de la nao Victoria, antes de afrontar la peligrosa ruta que les espera. ${ }^{71}$

En enero de 1522 temiéndose poder estar bajo orden de busca y captura por la Corona de Portugal, deciden arriesgarse a hacer el último aprovisionamiento en la Isla de Timor, para iniciar una ruta ya sin escalas y a la desesperada hasta su destino en Sanlúcar de Barrameda. ${ }^{72}$

En el viaje de vuelta por la ruta oriental, navegan con rumbo sud-oeste, transitando por mitad del Océano Índico, muy alejados en todo momento de las costas continentales de Asia y África, durante otra larguísima travesía, sin posibilidad de contacto con tierra firme, ni de aprovisionamiento, ni de descanso, siempre temerosos de encontrarse con los portugueses.

El 6 de abril de 1522, cuando alcanzan el Cabo de Buena Esperanza, "apenas les quedan víveres, ni agua"73. Se ven obligados a permanecer durante nueve semanas frente al Cabo, a la espera de vientos favorables que les permitan proseguir, con las velas plegadas para no ser descubiertos, soportando tempestades y dando muestra de su gran pericia marinera.

\subsection{Captura en Cabo Verde}

Durante la travesía atlántica, mueren de escorbuto ${ }^{74}$ e inanición, casi a razón de uno al día ${ }^{75}$. Elcano decide jugársela y hacer escala en Cabo Verde, aun a riesgo de ser descubiertos y apresados. E1 9 de julio de 1522 llegan a Cabo Verde. Pese a que omiten su procedencia y el nombre de la expedición, son descubiertos al pagar con especias los víveres que precisan. En la huida 18 hombres son capturados. Sobre ellos afirma la $\mathrm{RAH}$ :

"Los tripulantes de la Trinidad, apresados por los portugueses, no pudieron regresar hasta varios años después, cuando fueron liberados al pactar las coronas de Castilla y Portugal un acuerdo sobre la posesión de las Molucas. ${ }^{, 76}$

En Cabo Verde, preguntan la fecha y descubren el desajuste del calendario con el que cuentan los días, han ganado 24 horas, lo cual constituye la

\footnotetext{
71 Cronología tomada de V Centenario de la I Vuelta al Mundo, disponible en http://vcentenario.es/

${ }^{72}$ Ibidem.

${ }^{73}$ Ibidem.

${ }^{74}$ Enfermedad causada por avitaminosis $\mathrm{C}$ al no ingerir alimentos frescos durante mucho tiempo.

${ }^{75}$ Cronología y datos tomados de V Centenario de la I Vuelta al Mundo, disponible en http://vcentenario.es/

${ }^{76}$ REAL ACADEMIA DE LA HISTORIA, idem, p. 3
} 
prueba cronológica irrefutable de la efectiva circunnavegación del globo que han realizado.

Finalmente, el 6 de septiembre de 1522, 18 hombres famélicos y enfermos entran en la bahía de Sanlúcar de Barrameda, después de recorrer 14.460 leguas de navegación ${ }^{77}$, unos $80.000 \mathrm{~km}^{78}$

\subsection{Culminación de la gesta: «Primus circumdediste me»}

La expedición culminó el objetivo de alcanzar la isla de Maluco (Molucas) y traer al menos una embarcación cargada de especias. Es la evidencia del logro de la expedición en su objetivo comercial y económico.

"Cuando Juan Sebastián Elcano llegó a Sanlúcar de Barrameda, lo primero que hizo fue escribir una carta a Carlos I, resaltando no las penalidades, ni el camino recorrido, ni el encuentro con las islas de la Especiería, sino el hecho de haber conseguido circunnavegar la tierra por primera vez en nombre del Rey Emperador.",79

Carlos I recibió a los supervivientes en Valladolid y concedió a Elcano y a sus hombres pensiones vitalicias y escudos de armas.

En enero de 1523, Carlos I reconoce los méritos y el buen servicio a Juan Sebastián Elcano como capitán que ha conseguido hallar la citada Isla de la Especiería y traer de vuelta una nave y su cargamento. El rey le reconoce las fatigas sufridas y ordena sea pagado:

"Nos el Rey Emperador semper augusto, Rey de Romanos; la Reina su madre y el mismo Rey su hijo. Hacemos saber á vos los nuestros oficiales de la nuestra casa de la contratación de la especería, que acatando lo que Juan Sebastian del Cano capitan de la nao Victoria, una de las cinco naos de la armada que enviamos al descubrimiento de la especería, de que fué por Capitan General Fernando de Magallanes ya difunto, nos ha servido en el dicho descubrimiento de la dicha especería, y á los muchos y grandes trabajos que en él ha pasado y en traer la dicha nao Victoria con su buena industria y trabajo cargada de especería, y con ser el primero que descubrió el trato de la dicha especería de estos nuestros reinos, y enmienda y gratificacion dello, nuestra merced y voluntad es que haya $\mathrm{y}$ tenga de Nos por merced asentados en esa casa para en toda su vida qui-

\footnotetext{
${ }^{77}$ Cronología y datos tomados de V Centenario de la I Vuelta al Mundo, disponible en http://vcentenario.es/.

${ }_{78}$ España Ilustrada. Primera vuelta al mundo de Magallanes y Elcano. Disponible en http://spainillustrated.blogspot.com/2012/02/primera-vuelta-al-mundo-por-magallanes.html

${ }^{79}$ REAL ACADEMIA DE LA HISTORIA, idem, p. 3
} 
nientos ducados de oro en cada un año. Por ende Nos vos mandamos que lo pongades y asentades así en los nuestros libros y nóminas de las mercedes y asiento. (...) Fecha en Valladolid a 23 dias del mes de enero del nacimiento de nuestro Salvador Jesucristo de 1523 años.-Yo el Rey.Yo Francisco de los Cobos secretario de sus cesáreas y católicas Majestades lo fice escribir por su mandado. $" 80$

El rey Carlos I concede una renta vitalicia anual de 500 ducados de oro a Juan Sebastián Elcano como retribución por su buen servicio y como compensación por todas las penalidades que ha padecido, pero además le concede un escudo de armas, coronado por un globo terrestre con la leyenda "Primus circumdediste me" ${ }^{\prime \prime 1}$.

La ampliación de los confines del mundo conocido y del horizonte de influencia de nuestra nación quedaba recogida también en los propios emblemas de la Monarquía Hispánica y en el escudo de España, tal como refiere González Fernández:

"El emblema Plus Ultra lo adoptó Carlos como divisa del Toisón de Oro desde su subida al Trono de la Monarquía Española. La vela mayor del barco Real que llevaba a Don Carlos a los Reinos españoles estaba pintada de la siguiente manera: se veía a Cristo en la cruz entre la Virgen María y San Juan Evangelista, todo ello flanqueado por las dos columnas de Hércules. El emblema y la divisa fueron pensadas para Carlos por el humanista milanés Luigi Marliano, amigo de Pedro Mártir de Anglería. Con el tiempo, la divisa Plus Ultra llegó a ser considerada como símbolo de la extensión de la Monarquía Española en el Nuevo Mundo." 82

Con la decisiva ampliación del mundo conocido, protagonizado por nuestra nación al inicio de la Edad Moderna, hubo de suprimirse en el escudo de España la leyenda del Non Plus Ultra, de origen romano, que venía a significar No hay tierra más allá ${ }^{83}$, por la leyenda que todavía figura en el escudo de España, Plus Ultra, como explica González Fernández:

\footnotetext{
${ }^{80}$ FERNÁNDEZ NAVARRETE, M., SALVÁ, M. y SAINZ DE BARANDA, P., Idem, p. 248-249.

${ }^{81}$ Expresión latina, en español: "El primero que me rodeaste".

${ }^{82}$ GONZÁLEZ FERNÁNDEZ, E, Filosofia política de la corona en Indias. La Monarquía Española y América. Fundación Ignacio Larramendi, $3^{\mathrm{a}}$ ed., Fundación Ignacio Larramendi, Madrid, 2010, p. 113.

${ }^{83}$ Los límites de la Península Ibérica, concretamente, Finisterre, marcaban los confines del mundo conocido hacia el Oeste en la época romana. Finibusterre, proviene, según la RAE, del latín finübus terrae; literalmente "en los confines de la tierra". DRAE, disponible en https://dle.rae.es/?id=Hy1MuSI
} 
"Las legendarias columnas de Hércules fijaban los límites occidentales del Orbe con la inscripción Non Plus Ultra. Según la leyenda, ya no había más tierras al Oeste de aquella última frontera. Pero la Corona Española hizo trocar el negativo y estrecho lema por el afirmativo y amplísimo Plus Ultra: Más Allá. Las dos columnas de Hércules pasarían a formar parte del escudo de España, una a cada lado, de plata su fuste, de oro su basa y su capitel, liadas con una lista de gules, cargada con la divisa PLUS (en la columna diestra) y ULTRA (en la siniestra), surmontada cada una, respectivamente, de Corona Imperial y de Corona Real. Las dos columnas aparecen representadas en ese escudo sobre el agua del mar que abrió el camino del Nuevo Mundo a la comunicación con el Antiguo, como aludiendo al concepto filosóficopolítico de la Universitas Christiana." ${ }^{" 84}$

Es significativo este cambio en los emblemas de la Monarquía Hispánica conforme se ampliaban los espacios de proyección geográfica y los ámbitos de influencia política de nuestra nación merced a las grandes expediciones marítimas, como reflejo de una nueva mentalidad de la Corona Española.

\section{PRINCIPALES DESCUBRIMIENTOS Y SIGNIFICACIÓN DE LA EXPEDICIÓN}

\subsection{Constatación de la esfericidad de la Tierra.}

El viaje de circunnavegación de la Tierra supone un evento científico de primer orden al suponer la primera verificación empírica de la esfericidad terrestre que durante siglos había sido negada y cuestionada. Aunque la esfericidad de la Tierra se había sostenido ya en la astronomía griega, por parte de filósofosmatemáticos como Pitágoras ${ }^{85}$, Platón ${ }^{86}$, su discípulo Eudoxo ${ }^{87}$, y su colaborador, Calipo ${ }^{88}$, o, ya con una base científica-observacional, por Aristóteles ${ }^{89}$, sin

${ }^{84}$ GONZÁLEZ FERNÁNDEZ, Ibidem.

${ }^{85}$ Diógenes Laercio afirma que Pitágoras (569 - 475 a C.) fue el primer pensador griego en sostener la esfericidad de la Tierra. En realidad, no solo de la Tierra, sino de todos los astros que se contemplan en el firmamento. Como es sabido, Aristocles, alias «Platón» tuvo contacto con la escuela pitagórica en sus viajes a Sicilia, a la que viajó, al menos en dos ocasiones, como queda reflejado en la Carta VII, dejando un rastro evidente en su concepción filosófica y cosmológica.

${ }^{86}$ Platón sostuvo la esfericidad de la Tierra en diversos diálogos, en el Timeo o el Fedón, pero su concepción permaneció en el ámbito de la especulación filosófica, al no aducir razones observacionales o científicas.

${ }^{87}$ Su discípulo Eudoxo de Cnidos (390 - 337 a C.), matemático y astrónomo, fue el primero en plantear un modelo planetario basado en un sistema matemático de esferas homocéntricas, aunque precisaba de correcciones que permitiesen explicar las retrogradaciones para solventar las deficiencias observacionales del modelo, o salvar las apariencias, según la célebre expresión de Galileo Galilei. Con Eudoxo de Cnidos colaboró, precisamente en las correcciones de su modelo astronómico, su discípulo Calipo.

${ }^{88}$ Calipo de Cícico $(370$ - 310 a C.) revisó el sistema de Eudoxo y amplió el número de 
embargo la concepción esférica permaneció, durante siglos, en el ámbito de la especulación filosófica característica del pensamiento helénico.

Al inicio de la Edad Moderna no existía la certeza, ni la evidencia científica de su esfericidad. Tienen razón los epistemólogos, como Thomas S. Kuhn o Gustavo Bueno, al apuntar, frente a muchos historiadores, que la circunnavegación no se trató de una mera verificación empírica sin más. De hecho, los cálculos que se realizaban sobre las dimensiones de la Tierra eran vagos y erróneos, como bien pudieron constatar los expedicionarios españoles en su travesía por el Pacífico con las penalidades, fatiga e incertidumbre que navegar por un océano que ocupa un tercio de la superficie terrestre les supuso. Hasta ese momento se sabía de su existencia, pero se conceptualizaba como un mar, no había sido explorado y se ignoraba su dimensión real, que se comprobó sobre el terreno que excedía todos los cálculos previstos y previsibles.

En el ámbito científico, hay que hacer notar que entre las muchas y notables contribuciones que España ha realizado a la ciencia universal, la de la primera circunnavegación de la Tierra probablemente sea la más decisiva respecto a su momento histórico y la posteridad, porque supuso la primera demostración empírica de que la Tierra era redonda.

esferas hasta 33. Un cráter lunar lleva precisamente el nombre de Calippus en reconocimiento a su aportación a la investigación astronómica. Calipo de Cíclico colaboró, a su vez, con Aristóteles en Atentas.

${ }^{89}$ Aristóteles conoció el modelo astronómico de Eudoxo y Calipo, aunque lo contempló con un valor real que difería del valor instrumental con que al parecer estos astrónomos defendieron su sistema matemático-geométrico. Es característico del pensamiento aristotélico hacer una revisión crítica de todo el pensamiento precedente. En su concepción astronómica, Aristóteles replanteó el modelo de Eudoxo y Calipo, ampliándolo hasta 55 esferas, y, a diferencia de Platón, el de Stagira sí ofreció argumentos físicos y observacionales directos para sustentar una concepción esférica de la Tierra, particularmente en sus obras Sobre el Cielo y Meteorología. Aristóteles adujo tres argumentos distintos, todos ellos derivados de fenómenos observables: 1) en los eclipses lunares la sombra que proyecta la Tierra sobre el astro lunar es curvada, 2) las estrellas parecen variar su altura en el horizonte cuando cambia la posición del observador en la Tierra, concretamente la posición observada de la Estrella Polar al ser contemplada desde Grecia y desde Egipto, hecho que solo puede explicarse si la superficie terrestre es curvada y no plana como se suponía (ello le permitió incluso hacer una estimación aproximada, aunque errónea, de su tamaño que cifró en 400.000 estadios) y 3) el hecho de que cuando se aproxima un barco a tierra, en un día despejado y con buena visibilidad, primero se observan las velas y luego el casco. La teoría aristotélica fue completada e integrada en el sistema de Ptolomeo, ya en el siglo II, conformando un sistema astronómico de epiciclos y deferentes que perduró hasta la revolución heliocéntrica, llevada a cabo por Copérnico, Kepler y Galileo Galilei, durante el siglo XVII. Como es sabido, la revolución heliocéntrica se inicia en el siglo XVI, con el De revolutionibus orbium coelestium, obra redactada en la misma época de la expedición circunnavegadora de Magallanes y Elcano, entre 1503-1531, aunque es publicada póstumamente en 1543, dando comienzo a una revolución astronómica y científica, que de nuevo es postulada en sus inicios con un valor instrumental por parte del monje-astrónomo alemán Nicolás Copérnico, que releyó las tesis pitagóricas, pero no se atrevió a dar valor de realidad a su modelo astronómico. 
El epistemólogo Thomas S. Kuhn en su obra sobre la revolución copernicana deja constancia de la relevancia científica de estos viajes de Colón, primero, y de Magallanes y Elcano, después:

"Columbus' voyages and the subsequent travels of Magellan and others provided observational evidence for beliefs that had previously been derived solely from theory, and they supplied science with many unanticipated observations besides. The voyages would not have been undertaken, and the novel observations would not have accrued to the sciences, if a conceptual scheme had not pointed the way"90

Los viajes de Colón, así como los ulteriores de Magallanes y Elcano, y de otros navegantes españoles que les siguieron, proporcionaron evidencias observacionales a convicciones que hasta entonces solo se recogían en un esquema teórico, no evidente, no intuitivo. Por ello, estos marinos enriquecieron el edificio científico con una serie de observaciones absolutamente novedosas e insospechadas. Tales travesías nunca hubieran sido concebidas y emprendidas, ni las nuevas observaciones que de ellas se derivaron, habrían enriquecido las ciencias, sin un esquema conceptual que mostrara previamente el camino a seguir, la posibilidad efectiva de su realización. Para el autor de la Estructura de las revoluciones científicas ${ }^{91}$, tales viajes no serían posibles sin un esquema teórico previo que las hicieran conceptualmente viables, aunque subrayaba expresamente el enriquecimiento y la aportación a la ciencia que -en sí mismas- supusieron para la ciencia y la cosmovisión de la época.

En la misma línea, el filósofo y epistemólogo español, Gustavo Bueno, destacaba específicamente la relevancia científica de estas travesías, que tienen como trasfondo necesario un potente desarrollo epistemológico y de liderazgo en la innovación técnica de nuestra nación al inicio de la Edad Moderna ${ }^{92}$ y que

${ }^{90}$ KUHN, T.S., The Copernican Revolution. Planetary Astronomy in the Development of Western Thought (1962), Harvard University Press, Cambridge, Massachusets and London, 1995, p. 40. (Hay traducción española: La revolución copernicana. La astronomía planetaria en el desarrollo del pensamiento occidental) Harvard University Press, Cambridge, 1971).

${ }^{91}$ KUHN, T.S., The Structure of Scientific Revolutions (1962), International Encyclopedia of Unified Science, Editor-in-Chief: Otto Neurath, Associate Editors: Rudolf Carnap \& Charles Morris. The University of Chicago Press, Chicago, 1970. (con traducción española: La estructura de las revoluciones científicas, FCE, México DF., 1971).

${ }^{92}$ Sobre los medios y el instrumental de navegación, Comellas recoge los diversos avances, empezando por los medios de transporte: las ágiles carabelas, luego las naos, más grandes y resistentes, más apropiadas para las largas travesías oceánicas; sobre el instrumental: la quilla y el timón de codaste, que mejoraron la maniobrabilidad de las embarcaciones, los mapas portulanos, más detallados y precisos, la brújula y la rosa de los vientos, que permitían orientarse sobre los mapas, el astrolabio y el cuadrante, para establecer la posición en relación con los astros, pero, con todo, concluye el historiador esta referencia a los medios, aludiendo a un factor más decisivo: "Pero todo este instrumental no hubiera servido más que para navegaciones convencionales, si no 
van a dar como resultado la hegemonía española de los siglos siguientes. Ésta vendrá como resultado de un afán descubridor, propio del hombre renacentista, que encarnan Colón o Magallanes, pero también de una nueva mentalidad expansiva, organizada y sistemática, promovida por la Corona Española a la que no es ajena la universalidad del mensaje cristiano y la finalidad evangelizadora.

El filósofo asturiano situaba este acontecimiento en el marco de un proyecto político sistemático, un plan de Estado ${ }^{93}$ organizado, de ampliación de los ámbitos de influencia de la Monarquía Hispánica al inicio de la Edad Moderna ${ }^{94}$. Se trataba de un plan sistemático, concebido y trazado por los Reyes Católicos, motivado e impulsado por la universalidad de su cosmovisión cristiana, aunque su realización y culminación tuviera lugar ya tras su muerte. Así lo explicaba el difunto filósofo:

"Este objetivo en realidad se cumplió, ya desaparecidos los Reyes Católicos, con el viaje de Juan Sebastián Elcano, quién muerto Magallanes a manos de los malayos y capitaneando la nave «Victoria», pudo desembarcar en las Molucas ( 8 de noviembre de 1521), en donde fue recibido nada menos que por el sultán Almanzor: se había, por tanto, conseguido el objetivo de tomar contacto con los musulmanes navegando constantemente hacia el Poniente; la «Victoria», cargada de especias, y tras pasar el Cabo de Buena Esperanza, volvió a Sanlúcar el 7 de septiembre de 1522. El concepto práctico de la esfe-

hubieran existido otros motivos de fondo que condujeron a la realización de la aventura de buscar aquello de lo que aún no tenían noticia. Uno de esos motivos fue la curiosidad del hombre renacentista, deseoso de llegar más allá, «plus ultra», de buscar para conocer. El mismo Colón explicaba a las Reyes Católicos que «el afán de conocer el mundo es el que lleva al hombre a descubrir nuevas tierras." (COMELLAS GARCÍA-LLERA, JL, La primera vuelta al mundo, Rialp, Madrid, 2012, p. 14).

${ }^{93}$ BUENO G., La teoría de la Esfera y el Descubrimiento de América, disponible en http://www.filosofia.org/rev/bas/bas20101.htm

${ }^{94}$ Julián Marías, aunque subraya la participación y la cooperación entre la Corona y la Iglesia en las expediciones ultramarinas españolas, enfatiza la limitación de los recursos y la participación de la iniciativa privada en unas empresas, cuya finalidad nunca fue exclusivamente económica, sino también descubridora y evangelizadora:

"Toda la dilatación transoceánica de España presenta una estructura social y política de extrema originalidad. Se trata casi siempre de iniciativas privadas, de individuos o pequeños grupos con recursos inverosímilmente limitados (desde las tres naves de Colón, la mayor de 140 toneladas, hasta los 450 hombres con que Hernán Cortés vence al imperio azteca $\mathrm{y}$, con los otros pueblos mexicanos, construye ese gran país que se llamó el Reino de la Nueva España). No se trata de grandes expediciones oficiales, de escuadras y ejércitos mandados por el Estado; tampoco de grandes compañías de carácter primariamente económico.

Pero descubridores, exploradores, conquistadores, pobladores fundadores están ligados desde el comienzo a la Corona y a la Iglesia, que a su vez actúan en estrecha relación. La bula pontificia que señala límites entre España y Portugal es una división de la misión evangelizadora, condición de toda la empresa ultramarina. Al mismo tiempo, todo se hace en nombre de los Reyes (o del Rey posteriormente). Se entiende, de la Corona de Castilla, que es la que emprende los descubrimientos y sus consecuencias." (MARÍAS, J., España inteligible. Razón histórica de las Españas, Alianza Editorial, Madrid, 2014, p. 179). 
ricidad de la Tierra, que había abierto teóricamente la posibilidad del descubrimiento de América, se realizó, de modo ejercido, de la única manera posible, es decir, llevándolo a cabo operatoriamente, por Juan Sebastián Elcano, y de ello fueron plenamente conscientes quienes inspiraron la leyenda que figuró en el globo que Carlos V le dio como cimera: «Primum circumdedisti me»." $" 95$

En realidad, para Bueno, también hay una continuidad política, porque en tiempos de Carlos I de España se consuma el proyecto trazado por los Reyes Católicos. Es decir, en el siglo XVI asistimos a una renovación de un impulso que se puede rastrear ya antes de Fernando e Isabel, en el tiempo de la Reconquista.

"Será preciso desbordar los límites peninsulares, seguir acorralando a los mahometanos en África y aun tratar de cogerlos por la espalda en la ruta del Poniente hacia las Indias, que Colón venía proponiendo a los Reyes Católicos por aquellos años. No puede olvidarse, sin incurrir en anacronismo, que esta razón estratégica es la que movió a los Reyes Católicos para apoyar el proyecto de Colón." ${ }^{96}$

El filósofo recordaba que detrás del apoyo de los Reyes Católicos al proyecto de Colón hay también una razón estratégica. Los Reyes Católicos, que se encontraban consumando la unificación territorial de la Península, en una confrontación militar directa con los musulmanes, ofrecen su apoyo a Colón por razones estratégicas. Se puede discutir que fuera solo por tales razones, pero no obviar, que también estaban presentes.

Para Bueno el impulso expansionista del origen de la Reconquista, en el siglo VIII, se renueva en el siglo XVI, bajo unas nuevas coordenadas políticas durante el reinado de Carlos I:

"De hecho, y tras el inesperado descubrimiento de América (que Colón seguirá confundiendo con las Indias orientales, con la China o con el Japón), la vuelta al globo terráqueo pudo darse por primera vez, y Elcano pudo recibir de Carlos I una divisa, en la que figuraba la Tierra con la leyenda Primus circumdedisti me. Fue desde España, por tanto, desde donde partió la primera globalización, y en su sentido más literal, si recordamos que globo es, según nos dice Cicerón, la traducción latina del término griego sphairos (esfera)."

\footnotetext{
${ }^{95}$ BUENO G., La teoría de la Esfera y el Descubrimiento de América, disponible en http://www.filosofia.org/rev/bas/bas20101.htm

${ }^{96}$ BUENO, G., España no es un mito. Claves para una defensa razonada, Temas de Hoy, Madrid, 2005, pp. 74-75.
} 
El Descubrimiento de América realmente es inesperado, hasta para el propio protagonista, Cristóbal Colón, que vive y muere convencido de haber alcanzado las Indias, como también refiere Spate ${ }^{97}$. Lo que plantea Bueno es que «América» no existía antes de la llegada de los españoles, como supone un cierto realismo ingenuo o vulgar. No se presuponía su existencia y se descubrió. Sin embargo, tampoco es una mera invención ${ }^{98}$. Bueno considera que, desde una perspectiva epistemológica, estamos ante un descubrimiento constitutivo ${ }^{99}$, que no es meramente des-velador, des-cubridor en el sentido de la aletheia griega. No es un simple hallazgo o descubrimiento manifestativo $^{100}$, en la terminología de Bueno, sino constitutivo de una novedad que es lograda a partir de una maduración de la concepción esférica del mundo $^{101}$ que se produce en los siglos XV y XVI.

Es interesante la reflexión que hace Gustavo Bueno poniendo de relevancia que ambos eventos asumen la posibilidad efectiva de la navegación hacia el Oeste y el presupuesto gnoseológico de la esfericidad de la Tierra, bien sea con una motivación estratégica, para «coger por detrás a los árabes», en tiempo de los Reyes Católicos, como buscará la empresa de Colón, que finalmente llegará a América (aunque carezca de conciencia de su descubrimiento); o bien sea para alcanzar las islas de la Especiería, ya en la época de Carlos I, como pretenderá la expedición de Magallanes-Elcano y que, de facto, circunvalará por vez primera la Tierra.

El presupuesto gnoseológico de la empresa de Colón en tiempo de los Reyes Católicos, tal como subraya Bueno, es verdaderamente realizado por Elcano ya en tiempos de Carlos I. Por lo tanto, ambos eventos, Descubrimiento de América y Primera Circunvalación de la Tierra, se hallan vinculados no solo por participar de un mismo proyecto político, cultural y religioso, trazado por los Reyes Católicos, sino de un mismo presupuesto gnoseológico que, con distintas finalidades en cada momento histórico, posibilitó estas expediciones españolas.

No deja de ser llamativo que un filósofo como Bueno, militante en el materialismo ateo, que no participaba de la fe cristiana, identifique de forma tan clara los elementos espirituales y religiosos motivadores y conductores del proceso. Resulta particularmente sorprendente y lúcida la relevancia que otorga a la pujanza de la cosmovisión cristiana que, procedente de la Reconquista, se afianza al inicio de la

\footnotetext{
${ }^{97}$ Spate afirma que Colón confunde sus propias Indias con las de Cathay. Como es sabido, Cathay es la denominación histórica alternativa para China en lengua inglesa. Cfr. SPATE, O.H.K., The Spanish Lake, (1979), The Australian National University, Camberra, 2004, p.2.

${ }^{98}$ BUENO G., La teoría de la Esfera y el Descubrimiento de América, disponible en http://www.filosofia.org/rev/bas/bas20101.htm

${ }^{99}$ Ibidem.

100 Ibidem.

${ }^{101}$ Ibidem.
} 
Edad Moderna y la torna católica y universal. Se trata de un proceso de expansión de unos referentes colectivos, conformados en el Medioevo, durante el proceso de Reconquista, y que, reasumidos por nuestra nación al inicio de la Edad Moderna, propiciaron su universalización y otorgaron a España, en un sorprendente corto plazo de tiempo, no solo el protagonismo del ensanchamiento geográfico del mundo conocido, sino también la hegemonía del mismo.

Algunos consideran que el éxito de tales expediciones fue o pudo ser una casualidad del destino, en la que también confluyó la buena suerte. ${ }^{102}$ No parece que la apelación a la casualidad, aunque no pueda descartarse, pueda ser mantenida como un elemento sustantivo de explicaciones que resulten racionalmente satisfactorias, científicamente modélicas, ni históricamente verosímiles. También la casualidad y la buena suerte operan bajo un presupuesto gnoseológico general que puede ser acertado o erróneo, y dos tentativas, como la de Colón y

${ }^{102}$ Sobre la casualidad en la travesía del Pacífico, José Luis Comellas García-Llera, por ejemplo, expone que: "Es una casualidad que Magallanes no se haya tropezado con grandes tormentas en el en el tramo final del Estrecho, donde son enormemente frecuentes; ni una tempestad del Oeste en el largo trayecto frente a la costa austral de Chile, cuando allí lo normal es que las tempestades lleguen una y otra vez del lado del mar; fue otra casualidad que la corriente de Humboldt le haya llevado tan tempranamente hacia el centro del océano, en lugar de empujarle hacia Perú o las Galápagos, pero así ocurrió. También fue una casualidad que al atravesar la línea equinoccial no se haya eternizado en las clamas ecuatoriales, pero no se encontró con las calmas. Fue una casualidad que el desplazamiento de la línea de convergencia intertropical no le haya sorprendido con lluvias y tormentas eléctricas, pero la verdad es que no ocurrió así. Como también es una casualidad que el error difícilmente explicable de pasarse al hemisferio norte le haya premiado con unos alisios más intensos que los del sur, que le permitieron navegar a casi doble de velocidad que en el otro hemisferio. Cualquiera de estas casualidades es perfectamente posible. Pero que se hayan registrado todas ellas a la vez resulta sorprendentemente inverosímil." (COMELLAS GARCÍA-LLERA, JL, La primera vuelta al mundo, Rialp, Madrid, 2012, p. 106). Y añade el catedrático que, tanta coincidencia, tantas casualidades seguidas y favorables, obligan a buscar algún tipo de explicación.

También apunta Comellas, en otro punto, que "la ruta elegida por Elcano fue, desde un punto de vista de la geometría esférica, absolutamente perfecta. (Y añade) Sin duda lo fue por casualidad. Un navegante desprovisto de esfera no hubiera podido adivinarlo, ni tampoco la esfera inspirada en Behaim o en cualquier otro-, que llevaba Magallanes le hubiera servido de gran cosa, puesto que ignoraba la existencia del Pacífico y de gran parte del Índico" (COMELLAS GARCÍA-LLERA, JL, idem, p. 161). La casualidad en este sentido debe ser entendida como la fortuna puntual al escoger una ruta adecuada, que, hallándose sumidos en una situación de total incertidumbre y desconocimiento, resultó acertada. Se podría considerar que, en la expedición de Colón, 30 años antes, hubo mala fortuna al no alcanzar las Indias, tal como pretendía. En todo caso, lo que no pudo ser casualidad era el presupuesto conceptual bajo el que ambas expediciones fueron ideadas, trazadas y realizadas y eso es lo que dos relevantes epistemólogos, como Thomas S. Kuhn, brevemente, y G. Bueno, con todo detalle, ponen de relieve, que ambas expediciones (y otras posteriores) operan bajo un mismo presupuesto gnosológico, que Kuhn denomina conceptual scheme y Bueno, un presupuesto gnoseológico logrado a partir de una maduración de la concepción esférica del mundo, un esquema general que es acertado con independencia de que el resultado fuera afortunado o no, exitoso o no. La buena suerte es, en todo caso, un imponderable dentro de un esquema conceptual general o un presupuesto epistemológico común, que podía ser correcto o incorrecto, y que, en el caso de Elcano, ciertamente, resultó, además de correcto, afortunado y exitoso. 
Magallanes, operaron bajo tal presupuesto epistemológico. No creemos necesario recordar que en ambas expediciones se ponía en riesgo, además del capital invertido por la Corona, la Iglesia y los inversores privados burgaleses, además del prestigio de nuestra nación y de la misma Corona, numerosas vidas humanas (como fatalmente hubo de lamentarse).

En todo caso, hay que hacer notar que, en lo que ambos epistemólogos, Thomas S. Kuhn y Gustavo Bueno, coinciden, es en que, a los dos eventos históricos capitales que acontecen al inicio de la Edad Moderna, Descubrimiento de América (1492) y Primera Circunnavegación de la Tierra (1522), subyace una misma concepción teórica, que es ajena al sentido común, no evidente, no intuitiva y no corroborada científicamente hasta entonces, de la esfericidad de la Tierra. Sin tal concepción subyacente, estos viajes no serían posibles, ni viables, ni concebibles, ni siquiera susceptibles de ser planteados con mínimas garantías a la Corona. Este dato no es historia de la expedición, ciertamente, pero sí condición científica necesaria de su misma posibilidad, presupuesto epistemológico imprescindible de su planteamiento y de su realización efectiva.

Desde un punto de vista histórico, no parece muy verosímil sostener que dos eventos de tal trascendencia, que acaban ampliando decisivamente el mundo conocido, universalizando la fe cristiana y otorgando a España la hegemonía mundial al inicio de la Edad Moderna, tienen lugar por mera fortuna, por una suerte de casualidad del destino, incluso aunque en ambos casos las dificultades y las adversidades, de todo tipo, pudieran haberlos frustrado. Más razonable parece pensar que tuvieron que confluir otros factores posibilitadores, subyacentes y patentes, aunque la fortuna, ciertamente, pudiera no ser adversa. Trataremos de identificar otros elementos adicionales.

\subsection{Descubrimiento del Estrecho de Magallanes.}

El hallazgo de un paso entre el océano Atlántico y el océano Pacífico constituye un descubrimiento geográfico y cartográfico de primer orden con una relevancia máxima para la navegación náutica durante siglos. De hecho, constituirá el único paso entre ambos océanos, desde el siglo XVI al menos hasta la construcción del Canal de Panamá, ya en el siglo XX (1914).

Es importante para la navegación náutica porque se trata de un estrecho canal natural en medio de un laberinto de islas e islotes, en una región de navegación muy compleja, caracterizada por la sinuosa orografía, el intenso oleaje, las fuertes corrientes y el alto riesgo de impacto contra las rocas. De hecho, ya en la aproximación a esa región la expedición pierde la nave Santiago.

Se sospechaba de la existencia de tal paso transoceánico, los españoles y los 
portugueses lo habían buscado en diversas expediciones precedentes ${ }^{103}$, los lusos incluso excediéndose de sus jurisdicciones territoriales en América ${ }^{104}$. La expedición de Magallanes - Elcano lo localizará finalmente, navegando mucho más al sur de lo inicialmente estimado. ${ }^{105}$

\subsection{Apertura de una nueva ruta hacia las especias, el oro de la época.}

Las especias constituían el principal objetivo comercial de la expedición y se vio culminado no solo por alcanzar el lugar de producción de las mismas en Maluco (Molucas), en sus diversas islas, sino traer de vuelta un cargamento, como muestra efectiva de su consecución. Hay que hacer notar que este objetivo perdió importancia con el tiempo, porque el incremento del comercio con las islas de la Especiería hizo descender los precios de estas.

Se abrieron nuevas rutas mundiales de comunicación y de comercio. Desde entonces, además de la peligrosa y larga Ruta de la Seda, que atravesaba Oriente Medio, y de la Ruta del Cabo, que bordeaba el continente africano y que navegando hacia el este, había sido abierta por los portugueses, tras la expedición de Magallanes-Elcano, queda referenciada una nueva vía hacia las Indias Orientales a través del Pacífico, que será precisada y cartografiada por los marinos españoles del siglo XVI y posteriores. Tal exploración, hará que al Océano Pacífico, el mayor del mundo, se le denomine el Lago español, The Spanish Lake en la obra homónima de O.H.K Spate ${ }^{106}$, según la célebre expresión acuñada por el historiador francés Lucien Febvre en su obra Séville et l'Atlantic.

${ }^{103}$ Por parte española, lo habían buscado, además de Juan Díaz de Solís, como señala Comellas, "posiblemente también Sebastián Caboto y Américo Vespucci, ambos al servicio de España". (COMELLAS GARCÍA-LLERA, JL, La primera vuelta al mundo, Rialp, Madrid, 2012, p. 64). Véase nota 46.

${ }^{104}$ El propio Pigafetta alude a esas expediciones precedentes en PIGAFETTA, A., Primer viaje alrededor del globo. La crónica en vivo de la expedición de Magallanes-Elcano 1519-1522, Civiliter, Sevilla, 2012, p. 19

${ }^{105}$ El fin del continente americano por el sur, no está muy lejos del Estrecho de Magallanes, como pudo comprobar, solo cinco años después de la expedición circunnavegadora, el español Francisco de Hoces, quien descubrirá el Cabo de Hornos, que demarca el fin de América por el sur. (Véase COMELLAS GARCÍA-LLERA, JL, La primera vuelta al mundo, Rialp, Madrid, 2012, pp. 87-88).

${ }^{106}$ SPATE, O.H.K., The Spanish Lake, (original, 1979), The Australian National University, Camberra, 2004. La obra del que fuera director de la Escuela de Investigación en Estudios sobre el Pacífico de Australia entre 1967 y 1972, se inicia precisamente rememorando y elogiando el libro Séville et l'Atlantic (Sevilla y el Atlántico) de Lucien Febvre, uno de los más grandes historiadores franceses, que es el que acuña esta expresión para poner de relevancia la labor exploradora de los españoles en el Pacífico. En el primer volumen de la obra de Spate que lleva por título The Pacific since Magellan, el geógrafo dedica un capítulo a la relación entre Sevilla y el Pacífico, parafraseando a Febvre, en su Séville et l'Atlantic, bajo el epígrafe Seville and the Pacific. 


\subsection{Descubrimientos etnográficos de nuevas islas y poblaciones}

Realizan numerosos descubrimientos etnográficos a lo largo de de la ruta, en diferentes latitudes. Desde su llegada a la región de la Patagonia, a cuyos habitantes denominan patagones por el gran tamaño de sus pies, a las poblaciones autóctonas de numerosas islas e islotes del Pacífico que descubren.

Sobre los pueblos que habitan el cono sur americano, en el viaje de ida, refiere Pigafetta lo siguiente:

"Estos pueblos se visten, como lo he indicado ya, de la piel de un animal, y con la misma cubren sus cabañas, que transportan donde más les conviene, careciendo de morada fija, pero yendo, como los bohemios, a establecerse ya en un sitio ya en otro. Se alimentan de ordinario de carne cruda y de una raíz dulce que llaman capac. Son grandes comedores: los dos que habíamos cogido se comían cada uno en el día una cesta llena de bizcochos y se bebían de un resuello un medio cubo de agua. Devoraban los ratones crudos y aun con piel. Nuestro capitán dio a este pueblo el nombre de patagones."

Como vemos, el cronista se sorprende de las costumbres nómadas de estos pueblos, de que comen la carne sin cocinar, de la variedad de maíz que se da en esas latitudes, etc.

Sobre las poblaciones autóctonas de la Isla de Guam, que habitan cerca de la Fosa de las Marianas, el punto más profundo del océano Pacífico y del planeta, refiere Pigafetta:

"Estos pueblos no conocían ley alguna, siguiendo solo su propia voluntad; no hay entre ellos ni rey ni jefe; no adoran nada; andan desnudos; algunos llevan una barba larga y cabellos negros atados sobre la frente y que les descienden hasta la cintura. Usan también pequeños sombreros de palma. Son grandes y bien hechos; su tez es de un color oliváceo, habiéndosenos dicho que nacían blancos, pero que con la edad cambiaban de color. Poseen el arte de pintarse los dientes de rojo y negro, lo que pasa entre ellos por una belleza." ${ }^{, 108}$

Como vemos, el cronista refiere no solo las características relativas a la fisonomía de los pueblos nativos, sino su sistema de organización social o tribal, sus creencias, sus costumbres, sus gustos estéticos, su forma de vestir, etc.

Descubren numerosas poblaciones y grupos étnicos hasta entonces desconocidos, especialmente en los archipiélagos de la región de Asia-Pacífico, con algunos de los cuales conviven durante meses, intercambian obsequios,

\footnotetext{
${ }^{107}$ PIGAFETTA, A., Idem, p. 27

${ }^{108}$ Ibidem, p. 39
} 
experiencias vitales y religiosas, y cuyas formas de vida quedan descritas y referenciadas en las propias crónicas de Pigaffeta. Algunos de ellos irán en el viaje de vuelta hacia España de la expedición formando parte de la tripulación.

\subsection{Primera globalización del mundo con una tripulación de procedencia diversa.}

Por medio de la expedición circunnavegadora se establecieron vínculos entre pueblos muy diversos, tal como recordaba el Rey Felipe VI, en la conmemoración de las Capitulaciones de Valladolid:

"Pueblos de África, América, Asia, Europa y Oceanía, de todos los mares y latitudes, se ligaron a través de vínculos personales, culturales, económicos, políticos y sociales. Incluso las tierras antárticas del sexto continente fueron avistadas entonces por naves hispanas."

Las consecuencias de la expedición se pueden cifrar en distintos ámbitos. Acaso una de las principales fue la aparición de una primera red de intercambios a escala mundial. Tal como manifestaba el académico de la historia, Martínez Shaw:

"Las consecuencias más inmediatas de la primera vuelta al mundo (que puede considerarse como la culminación de toda una serie de expediciones anteriores, especialmente llevadas a cabo por Cristóbal Colón, Vasco de Gama y Vasco Núñez de Balboa) fueron la inauguración de una red de intercambios intercontinentales, que fueron humanos, biológicos, agropecuarios, culturales y económicos, los cuales incluyeron la creación de redes comerciales entre los diversos continentes y la integración de los mismos en un sistema económico mundial. Este proceso, que implicó a todos los mundos, generó, paradójicamente, la aparición de un solo mundo y la posibilidad de concebir por primera vez una historia universal."

Se posibilita una primera conciencia de la unidad del globo, en medio de la constatación de la riqueza y diversidad del mundo en su sentido más literal, como bien recordaba G. Bueno:

${ }^{109}$ FELIPE VI, Palabras de su Majestad El Rey con motivo de la conmemoración de las Capitulaciones de Valladolid. Monasterio de Nuestra Señora de Prado. Valladolid, 22 de marzo 2018. Disponible en:

http://www.casareal.es/GL/Actividades/Paginas/actividades_discursos_detalle.aspx?data=6018

${ }^{110}$ MARTÍNEZ SHAW, C., Después del Cano. Repercusiones de la primera circunnavegación. En web V Centenario de la I Vuelta al Mundo, disponible en http://vcentenario.es/ 
"Fue desde España, por tanto, desde donde partió la primera globalización, y en su sentido más literal, si recordamos que «globo» es, según nos dice Cicerón, la traducción latina del término griego sphairos (esfera)"111

La esfera era, para los griegos, la figura geométrica perfecta, paradigmática, por su armonía intrínseca, que era constatable también en los astros del firmamento. La esfera es el símbolo de la universalidad y de la globalidad.

Globalidad implica también diversidad. En la misma expedición de bandera española iban castellanos, aragoneses, vascos y de otras zonas de España, pero también de los diversos territorios italianos, además de portugueses, con lo cual constituye en sí misma un primer grupo humano de procedencia diversa, aunque circunscrito al ámbito de influencia de lo que abarcaba la monarquía hispánica en aquella época. Se ha hablado de una primera globalización realizada per ibéricos, tal como recordaba el catedrático y académico de la historia, Carlos Martínez Shaw, sobre la significación de la empresa:

"La primera vuelta al mundo fue la pieza clave, o más aún, la clave de bóveda para que hoy podamos hablar de una primera globalización o de una primera mundialización. Una globalización que se hizo «per Ibericos», es decir, traduciendo la frase latina, por la mediación de las naciones ibéricas, por lo que el historiador francés Pierre Chaunu pudo titular un famoso libro «Les Philippines et le Pacifique des Ibériques», ya que Felipe II pudo establecer su soberanía sobre esas Islas Filipinas, que servirían para extender la influencia española por todo Extremo Oriente y por la Micronesia."

Filipinas se convertirá en un importante nudo de conexión transpacífico entre China y América, al tiempo que España continuará con la exploración del inmenso Pacífico, principalmente en busca de la Terra Australis, que la expedición bordeó sin apercibirse de su proximidad.

\subsection{Descubrimientos astronómicos de las constelaciones de Magallanes}

Observan fenómenos astronómicos hasta entonces inobservados como nuevas galaxias, muy próximas a la Tierra, pero que no pueden ser observadas desde latitudes mediterráneas o próximas a ellas, en ninguna época del año, por lo que

\footnotetext{
${ }^{111}$ BUENO, G., España no es un mito. Claves para una defensa razonada, Temas de Hoy, Madrid, 2005, p. 75

${ }^{112}$ MARTÍNEZ SHAW, C., Después del Cano. Repercusiones de la primera circunnavegación. En la web del V Centenario de la I Vuelta al Mundo, disponible en http://vcentenario.es/
} 
no pudieron ser referenciadas por la astronomía clásica, ni siquiera por la ciencia de la época con mejor instrumental.

La denominada Gran Nube de Magallanes, referenciada en astronomía por el acrónimo LMC, que alude a sus iniciales en inglés Large Magellanic Cloud, debe su nombre a que el capitán de la expedición española fue el primero en observar, referenciar y poner en conocimiento de occidente la existencia de esta nueva galaxia.

La peculiar posición de la galaxia LMC en relación a la Tierra, que hace que solo sea observable desde la posición sur de la elíptica solar, hizo que este relevante descubrimiento científico no pudiera llevarse a cabo hasta ser observado desde latitudes y posiciones que quedaban en las antípodas del mundo conocido.

\subsection{Descubrimientos de fauna y flora en distintas latitudes}

Dado que navegan desde regiones meridionales y tropicales hasta latitudes polares, descubren toda clase de animales y plantas hasta entonces desconocidas. Entre las especies más destacadas que identifican y caracterizan figuran las llamas, las focas, los pingüinos, los lobos marinos, así como numerosas clases de peces y aves. Sobre la fauna antártica, refiere Pigafetta la siguiente descripción de la misma:

"Costeando siempre esta tierra hacia el polo Antártico, nos detuvimos en dos islas que solo encontramos pobladas por pingüinos y lobos marinos. Los primeros existen en tal abundancia y son tan mansos que en una hora cogimos provisión abundante para las tripulaciones de las cinco naves. Son negros y parece que tienen todo el cuerpo cubierto de plumas pequeñas, y las alas desprovistas de las necesarias para volar, como en efecto no vuelan: se alimentan de pescados y son tan gordos que para desplumarlos nos vimos obligados a quitarles la piel. Su pico se asemeja a un cuerno.

Los lobos marinos son de diferentes colores y más o menos del tamaño de un becerro, a los que se parecen también en la cabeza. Tienen las orejas cortas y redondas y los dientes muy largos; carecen de piernas, y sus patas, que están pegadas al cuerpo, se asemejan bastante a nuestras manos, con uñas pequeñas, aunque son palmípedos, esto es, que tienen los dedos unidos entre sí por una membrana, como las nadaderas de un pato. Si estos animales pudieran correr serían bien temibles porque manifestaron ser muy feroces. Nadan rápidamente y solo viven de pescado." 113

${ }^{113}$ PIGAFETTA, A., Idem, p. 20 
Como vemos, hacen una descripción minuciosa de sus características anatómicas, de sus hábitats y de las formas de vida y alimentación que siguen las especies que habitan en la región antártica.

Sobre los animales que encuentran en otras latitudes, por ejemplo, los loros que habitan en las Molucas, afirma Pigafetta:

"Hay también mucha variedad de loros, entre otros algunos blancos que llaman catara, y unos rojos que se conocen con el nombre de nori, que son los más estimados, no solo por la belleza de su plumaje, sino también porque pronuncian más distintamente que los otros las palabras que se les enseñan." 114

Como se aprecia describe incluso las diversas variedades de loros que habitan las Islas de la Especiería referenciando sus llamativos plumajes y la posibilidad de domesticación y de condicionamiento para emitir sonidos similares a las palabras.

\subsection{Descubrimiento de nuevas enfermedades como el escorbuto}

Las condiciones de vida de la tripulación durante la travesía fueron muy duras. Tal como refiere Higueras Rodríguez, en una reciente aportación a un monográfico de la Sociedad Geográfica Española, sobre la dieta de la primera vuelta al mundo:

"Las condiciones de vida de la tripulación, durante las largas navegaciones sin proximidad de tierra, eran realmente penosas. Muy especialmente debido a la dureza de su precaria alimentación, una dieta marcada por la escasez de agua y la falta de alimentos frescos"115

Esta carencia en la dieta de alimentos frescos, frutas y verduras, mantenida durante meses de travesías oceánicas sin escalas, determinó la aparición de nuevas enfermedades, como el escorbuto, que se produce por una deficiencia de vitamina $\mathrm{C}$ en la dieta. El propio Pigafetta, cronista de la expedición, refiere así esta circunstancia en la travesía del Pacífico:

"Miércoles 28 de noviembre, desembocamos por el Estrecho para entrar en el gran mar, al que dimos en seguida el nombre de Pacífico, y en el cual

${ }^{114}$ Ibidem, p. 129

${ }^{115}$ HIGUERAS RODRÍGUEZ, MD., La dieta de vuelta al mundo. Alimentos básicos a bordo en el siglo XVI, en volumen monográfico «El viaje de los alimentos. Expediciones, descubrimientos y conquistas que produjeron el intercambio de alimentos entre distintos continentes», Sociedad Geográfica Española, $n^{\circ}$ 62, enero-abril, 2019, p. 31 
navegamos durante el espacio de tres meses y veinte días, sin probar ni un alimento fresco. El bizcocho que comíamos ya no era pan, sino un polvo mezclado de gusanos que habían devorado toda su sustancia, y que además tenía un hedor insoportable por hallarse impregnado de orines de rata." ${ }^{, 16}$

Tampoco el agua que ingerían era limpia, ni de buen sabor. A veces para poder beberla la diluían en vino o se tapaban la nariz para poder tomarla. Durante las largas travesías, la poca agua de que disponían la solían recoger de la lluvia y más bien la empleaban para poder reblandecer el cuero que ingerían para paliar el hambre. Continúa narrando Pigaffeta:

"El agua que nos veíamos obligados a beber estaba igualmente podrida y hedionda. Para no morirnos de hambre, nos vimos aun obligados a comer pedazos de cuero de vaca con que se había forrado la gran verga para evitar que la madera destruyera las cuerdas. Este cuero, siempre expuesto al agua, al sol y a los vientos, estaba tan duro que era necesario sumergirlo durante cuatro o cinco días en el mar para ablandarlo un poco; para comerlo lo poníamos en seguida sobre las brasas. A menudo aun estábamos reducidos a alimentarnos de serrín, y hasta las ratas, tan repelentes para el hombre, habían llegado a ser un alimento tan delicado que se pagaba medio ducado por cada una."

Los jugos estomacales son tan fuertes que cuando el ser humano pasa hambre prefiere ingerir incluso alimentos no comestibles, que dañan la salud, antes que soportar la acción de estos jugos gástricos corrosivos en el estómago vacío. Tal como hemos publicado sobre el problema del hambre en otro ámbito de investigación, este no se limita solo a mera deficiencia calórica, "no es solo desnutrición, sino malnutrición y falta de seguridad alimentaria que genera enfermedades." 118

${ }_{116}^{116}$ PIGAFETTA, A., Idem, p. 35

${ }^{117}$ Ibidem.

${ }^{118}$ SÁNCHEZ GARCÍA JL, Compromiso con la superación del hambre en el mundo: por una nueva humanidad. Presentación del volumen. En SÁNCHEZ GARCÍA, JL. (dir. y coord.) Superación del hambre en el mundo: Por una Nueva Humanidad. Estudio Interdisciplinar, ThomsonReuters Aranzadi, Pamplona, 2017, p. 17. En esta colaboración sobre el problema del hambre en nuestro tiempo, que forma parte de una línea de investigación multidisciplinar en que colaboran prestigiosos expertos y premios Nobel de distintas universidades de todo el mundo, referenciábamos que dietas que carecen de determinados micronutrientes (proteínas, calorías, vitaminas o minerales) no solo debilitan, sino que "condicionan, limitan y hasta imposibilitan el pleno desarrollo humano, dando lugar a enfermedades, carencias, retrasos, incapacidades o incluso la muerte" (ibidem). Tal sintomatología fue mostrada por muchos miembros de la expedición circunnavegadora, tal como refiere el propio Pigafetta, algunos de ellos hasta en sus últimas y fatales consecuencias. Muchos miembros de la expedición española no solo padecieron muchos de los síntomas de cansancio, debilidad, incapacidad, sino que padecieron enfermedades como el escorbuto e inclusive la muerte por el agravamiento de esta u otras enfermedades o por pura inanición. 


\section{LA FE Y LA EVANGELIZACIÓN, CLAVES DE LA VOCACIÓN CIVILIZADORA ESPAÑOLA}

\subsection{Dimensión evangelizadora con origen en los Reyes Católicos y el reino godo.}

La finalidad de la evangelización constituye una de las grandes motivaciones de la expedición española, pero también de su misma posibilidad y de su realización efectiva. En general, es difícil prescindir de la finalidad evangelizadora en las empresas descubridoras españolas al inicio de la Edad Moderna, si queremos verdaderamente poder comprender su sentido y sus motivaciones más profundas que deben rastrearse en la misma configuración cristiana de nuestra nación, no ya en su génesis moderna, en la época de los Reyes Católicos, sino del reino Godo cuando asumió la catolicidad como referente de su unidad política.

En el caso particular del tema que nos ocupa, la empresa circunnavegadora de Magallanes-Elcano, la fe y la evangelización constituyen referentes necesarios y condiciones sine qua non no solo de su posibilidad y de su motivación, sino de su misma realización efectiva, por la dureza de la travesía.

\subsection{Relevancia de la fe en la expedición: En el nombre del Señor.}

Hoy en día, en el contexto de una sociedad postmoderna, descreída y agnóstica como la actual, nos puede costar apercibirnos del influjo y del poder que pueden llegar a ejercer las convicciones y las creencias profundas en las motivaciones y las realizaciones de las personas; pero su influjo es realmente muy poderoso y va más allá de lo que probablemente estamos dispuestos a aceptar. Esta relevancia se hace particularmente visible y constatable especialmente en circunstancias extremas como las que se dieron y se vivieron en la arriesgada e incierta empresa circunnavegadora.

Si no resulta fácil comprender el significado que tenía la fe en la vida de estas personas desde nuestras coordenadas culturales, mucho más complejo resulta poder comprender el significado que los españoles del s. XVI otorgaban al sentido del honor, en toda su relevancia personal, familiar, social, incluso trascendente. Cuando a Magallanes se le exige desde la Corona defender "hasta la muerte el estandarte real que habría de enarbolar su buque o su capitana de flo$\operatorname{ta}^{119}$, bajo pena de muerte y nota de infamia" ${ }^{120}$ se está apelando a unos códigos que escapan a las escalas de valores actuales.

\footnotetext{
${ }^{119}$ En la terminología de la marina, se denomina capitana a la nave en la que se arbola la insignia del almirante, comandante o jefe de grupo. Si en la escuadra estuviese presente el rey, o fuese a bordo de alguna nave, a la misma se la denomina capitana real y visualmente se la identifica por arbolar el real estandarte.
} 
Ciertamente, hoy en día, desde la distancia mental con aquella época, se hace difícil poder apercibirse del sentido que se le asignaba al honor en el universo referencial simbólico y social del siglo XVI, que, por su vigencia, relevancia y trascendencia, excedía con mucho lo que hoy mutatis mutandi podríamos referir como el derecho al buen nombre, puesto que incluiría aspectos como el respeto social, la fama, el crédito o incluso el riesgo reputacional, pero no en un sentido individual, como lo entenderíamos hoy día, puesto que también se extendía al linaje familiar. Por otra parte, también tenía un sentido trascendente, la dignidad personal del hombre ante la eternidad, ante Dios.

Desde luego el sentido del honor estaba presente y operaba en la vida de estas personas, y tenía profundas repercusiones en sus escalas de valores y en sus comportamientos tanto en servicio como en privado. En muchos casos se concretaba en virtudes o actitudes exigibles como la de la lealtad, el decoro o el sacrificio personal, todas ellas referenciadas, algunas con gran minuciosidad, en la crónica de Pigafetta. De modo análogo y no desligado de ese sentido de la existencia, sino probablemente como fundamento último del mismo, tenían presente la fe religiosa y la dimensión trascendente de sus vidas, que concebían en el marco general de una cosmovisión cristiana del mundo regido por la providencia divina sobre el conjunto del mundo y sobre sus vidas.

\subsection{Momentos concretos de manifestación de la religiosidad}

La fe religiosa, desde luego, está presente en toda la expedición y se constata en muchos aspectos y momentos a lo largo de la misma: desde su partida y su configuración, desde los nombres escogidos para las naves: Trinidad, San Antonio, Concepción, Santiago y Victoria. La misma nao Victoria, que capitaneará Elcano en el viaje de retorno y con la que finalmente culmina la expedición, que debe su nombre a Santa María de la Victoria de Triana, en Sevilla.

Además de en la fe de los marinos, tanto de las tripulaciones como de los oficiales, de la oración en medio de las dificultades, de los capellanes que les acompañan, la fe se hace presente en muchos signos y momentos de la expedición: desde la interpretación religiosa de los fenómenos atmosféricos que presencian, en mitad del océano, como el Fuego de San Telmo, a los sentimientos de temor y vulnerabilidad ante las fuerzas de la naturaleza, signo visible del respeto por lo sobrenatural, el respeto por el misterio, el temor de Dios, también la fe y esperanza en su Providencia; pasando por los nombres que asignan a los accidentes geográficos que descubren: al más importante Magallanes lo

\footnotetext{
${ }^{120}$ REAL ACADEMIA DE LA HISTORIA, idem, p. 3
} 
bautiza De todos los Santos, conforme al santoral de la Iglesia Católica, al cabo que le precede De las Once mil Virgenes ${ }^{121}$; a las Filipinas, las denomina Magallanes, Islas de San Lázaro; pero también la celebración de la Eucaristía con los nativos, los símbolos cristianos y cruces que dejan a su paso en lugares destacados, enclaves o pasos relevantes, lugares emblemáticos, simbólicos, el sentido del decoro que refiere Pigafetta en el trato con los nativos, la evangelización de los pueblos que realizan, las numerosas conversiones, la dispensa de los sacramentos, en especial el del Bautismo, que supone la entrada a la fe cristiana. Pero, además, hay constancia de los testimonios y los testamentos que realizan en circunstancias extremas, como el referido del propio Juan Sebastián Elcano, reafirmando su plena adscripción a la Iglesia Católica y ordenando donativos a numerosas iglesias, ermitas, santuarios de la Virgen de su tierra, monasterios y asilos para los pobres de su Guetaria natal, como expresión cristiana de su última voluntad.

Respecto a momentos emblemáticos de religiosidad, cabe destacar la celebración de la Pascua con los nativos de la isla de Masawa, en las Filipinas, sobre la que refiere Pigafetta:

"Antes que comenzase la misa, el comandante aspergió a los dos reyes con agua almizclada. En el momento de la oblación, fueron, como nosotros, a besar la cruz, pero no hicieron el ofrecimiento, y en el momento de alzar, adoraron la eucaristía con las manos juntas, imitando siempre lo que hacíamos. En este instante, las naves, habiendo visto la señal, hicieron una descarga general de artillería. Después de la misa, algunos de nosotros comulgaron, y en seguida el comandante hizo ejecutar una danza con espadas, lo que produjo mucho placer a los soberanos." 122

El comandante de la expedición española les ofrece la cruz como símbolo de la protección divina, no solo ante las fuerzas naturales, sino de otras naves europeas que pudiesen llegar en un futuro a la isla. Añade el cronista:

"Después de esto, mandó traer una gran cruz adornada de clavos y de la corona de espinas, delante de la cual nos prosternamos, cosa en que también nos imitaron los isleños. Entonces el comandante, por medio del intérprete,

${ }^{121}$ El cabo sur del Estrecho de Magallanes se denomina Del Espíritu Santo, porque en esa región naufragó Juan Sebastián Elcano, en 1526, capitaneando una nave que se llamaba así, Sancti Spiritu. Con ello, los nombres de los dos ilustres marinos de la expedición española quedaron ligados para siempre al Estrecho: Cabo Virgenes, al cabo norte, tal como lo bautizó Fernando de Magallanes (hoy en suelo argentino) y Cabo Espíritu Santo, al cabo sur, en honor a Juan Sebastián Elcano (en territorio chileno).

${ }^{122}$ PIGAFETTA, A., Primer viaje alrededor del globo. La crónica en vivo de la expedición de Magallanes-Elcano 1519-1522, Civiliter, Sevilla, 2012, p. 51 
dijo a los reyes que esta cruz era el estandarte que le había sido confiado por el emperador para plantarla adonde quiera que abordase, y que, por lo tanto, quería levantarla en esta isla, a la cual este signo sería, por lo demás, favorable, porque todas las naves europeas que en adelante viniesen a visitarla, conocerían, al verla, que allí habíamos sido recibidos como amigos y no harían ninguna violencia ni a sus personas ni a sus propiedades; y que, aun en el caso que alguno de ellos fuese apresado, no tenía más que mostrar la cruz para que se le devolviese en el acto su libertad." ${ }^{, 123}$

Como se ve, la cruz es el verdadero estandarte de la expedición. La cruz como símbolo de divina protección, en un doble sentido: natural y sobrenatural. La protección natural derivaba de que la cruz servía como pararrayos en una región con fuertes tormentas eléctricas. En un sentido sobrenatural, la cruz les recordaría la fe en Cristo que nos hace hermanos e iguales ante Dios.

El cronista también refiere cómo la fe cristiana era aceptada y asumida de buen grado por los nativos. Aunque lo más sorprendente es cuando Pigafetta relata que Magallanes:

"Les hizo preguntar cuál era su religión, si eran moros o gentiles: a lo que contestaron que no adoraban ningún objeto terrestre; pero levantando las manos juntas y los ojos al cielo, dieron a entender que adoraban a un Ser Supremo, que llamaban Abba, lo que causó gran contento en nuestro comandante." $" 124$

Como es sabido, Abba es el nombre bíblico originario de Dios en lengua aramea. Es el mismo término que utilizaba Jesucristo, en su propia lengua aramea, para referirse al Padre. Es una referencia literal, teológicamente muy relevante y sorprendente.

Si alguien duda de la relevancia de la fe en las expediciones españolas, desde el inicio de la Edad Moderna, y de su referencialidad simbólica-cristiana, con una catolicidad realmente universal, no hace falta hacer grandes disquisiciones al respecto, baste recordarle que se pueden rastrear los itinerarios de las numerosas expediciones españolas por todo el mundo identificando los topónimos que, con un sentido o motivación cristiana, los españoles fueron denominando a todos los accidentes geográficos naturales que localizaron, los enclaves que descubrieron, así como las numerosas comunidades o ciudades que fundaron en los más remotos y recónditos lugares del mundo. Es una corroboración geográfica, fácilmente constatable y rastreable, que da cuenta, todavía hoy, de la relevancia de la fe, la simbología y la cosmovisión cristiana en la motivación de las

\footnotetext{
${ }^{123}$ Ibidem, pp. 51-52.

124 Ibidem, p. 52.
} 
expediciones españolas; presente y rastreable incluso, en un sentido personal, en las mismas vidas de muchos de los expedicionarios y descubridores españoles. El hecho de que este rastro se extienda por todo el mundo, hasta los lugares más recónditos del globo, es la huella indeleble de sus méritos humanos y de su catolicidad.

\subsection{La impronta civilizadora española.}

En su reflexión sobre la significación del viaje de Magallanes y Elcano, para tratar de comprender el sentido y alcance de la misma, el filósofo Julián Marías también parte, como hemos visto con Thomas S. Kuhn o Gustavo Bueno, de la conexión entre las dos grandes expediciones españolas al inicio de la Edad Moderna: el Descubrimiento de América (1492) y la Primera Circunnavegación de la Tierra (1522). Marías destaca, en primer lugar, que dos eventos tan relevantes de la historia de la humanidad, se producen en un sorprendente breve lapso de tiempo, casi concatenados:

"Exactamente treinta años después de la primera expedición de Cristóbal Colón, que llevó al descubrimiento de América, Elcano, con la pequeña nave Victoria, completó la primera vuelta al mundo. Parece difícil creerlo. Por esas fechas están descubiertos y explorados vastos territorios, en las Antillas, América Central, México, amplias penetraciones en Suramérica; y, por supuesto, fundaciones de ciudades en todas partes. A mediados del siglo XVI, los españoles dominan la mayor parte de América del Sur (salvo el Brasil), toda la América Central, la Nueva España y buena parte de lo que hoy son los Estados Unidos. Hay una ciudad americana que tiene tiempo de que a ella llegue el Gótico: Santo Domingo. La imprenta publica numerosos libros en México; en 1551, después del Estudio General de Santo Domingo, se fundan las Universidades de México y San Marcos de Lima (Harvard, 1636; Yale, 1701)."

Al poner en relación ambos eventos y contemplarlos en perspectiva histórica, el filósofo español pone de relieve la dificultad de quien trata de comprenderlos como dos eventos aislados, azarosos, fruto de una mera casualidad histórica. Si verdaderamente queremos comprender su sentido y cifrar su alcance debemos indagar en las condiciones de inteligibilidad de estos hechos, en las trayectorias que los posibilitaron y los conformaron, y en las motivaciones que portaba la civilización española al inicio de la Edad Moderna y que el filósofo

${ }^{125}$ MARÍAS, J., España inteligible. Razón histórica de las Españas, Alianza Editorial, Madrid, 2014, pp.177-8. 
cifra, entre otros, fundamentalmente en su fe católica y su afán civilizador conforme a la cosmovisión cristiana.

Lo interesante del ejercicio que hace Marías, es que, al concatenar todos estos grandes acontecimientos, y contemplarlos en conexión diacrónica, trazando los elementos de inteligibilidad de las trayectorias, como también hemos visto que hacen Gustavo Bueno, ó Thomas S. Kuhn, aunque este último sea para incidir en su relevancia científica, el filósofo de Valladolid esclarece el horizonte de sentido que posibilita la comprensión de los mismos en su significación cultural, permitiendo realmente apercibirse de su relevancia histórica y comprender su significado y el marcado alcance evangelizador y civilizador de las expediciones españolas, que constituye una elemento característico y diferenciador de las empresas españolas frente a otro tipo de expediciones que realizarán otras naciones europeas de la época y posteriormente.

Ese afán evangelizador y civilizador característico de los españoles al inicio de la Edad Moderna se constata, por ejemplo, en la temprana introducción de los dos factores promotores del saber por excelencia en aquel tiempo, como son, la universidad y la imprenta en América. Este dato es muy relevante. ¿Por qué los españoles del siglo XVI llevan a las tierras recién descubiertas los factores más innovadores de promoción del saber y la cultura de su tiempo? ¿Acaso no iban allí en busca de riquezas naturales con una mentalidad meramente extractiva y expoliadora de sus recursos, sin querer incidir para nada en el desarrollo autóctono de los pueblos?

Creemos que la presencia de la universidad y la imprenta, tan temprana en los territorios americanos, las primeras datan de tan solo 50 años después del descubrimiento, solo pueden encontrar justificación en que realmente no eran consideradas colonias, territorios donde solo se pretendía una explotación de los recursos naturales, sino territorios y reinos españoles de ultramar. Por eso, los españoles llevan a esos lejanos territorios, que también consideran españoles, la universidad, la imprenta, y, en definitiva, la civilización. Ciertamente, también los males y problemas que la civilización entraña. Resulta muy complicado llevar lo bueno, sin llevar lo malo. Toda opción necesariamente limita y posibilita. Con todo, podemos concluir que la expansión espiritual y cultural que llevan a cabo los españoles al inicio de la Edad Moderna es civilizadora porque es religiosa y evangelizadora. También es geográfica, cartográfica y descubridora. Prosigue Marías:

“Descubierto el Pacífico por Núñez de Balboa (1513), seis años después lo navega Magallanes desde el Sur, muere en la Filipinas, prosiguen los descubrimientos, y Elcano continúa hasta dar la vuelta al mundo (la segunda cir- 
cunnavegación, la de Francis Drake, se hará esperar cincuenta y ocho años, hasta 1580). América se llena de ciudades construidas por los españoles, de iglesias, palacios, obras de arte (se calculan en 600.000 los cuadros pintados por la Escuela Cuzqueña en tres siglos de Virreinato). Se estudian las lenguas indígenas, se componen vocabularios de ellas, se estudia minuciosamente la geografía, la fauna, la flora, la minería."126

El filósofo destaca la vocación descubridora de los españoles en relación con su labor civilizadora y promotora del saber y del arte, realmente sorprendente para su época. También refiere el interés por el estudio de las peculiaridades etnográficas, lingüísticas, botánicas y de recursos naturales de las nuevas tierras. Pero, con todo, prevalece su afán descubridor. Afirma Marías:

"Prosigue la exploración del Pacífico: Islas Marquesas, Salomón, Nuevas Hébridas, Nueva Guinea, Australia. Las Filipinas, Marianas, Carolinas, Palaos quedarán unidas a la Corona hasta fines del siglo XIX."127

Todos estos territorios quedan ligados a la Corona española durante siglos ${ }^{128}$. Hay una vocación de permanencia en ellos, se establecen unos vínculos que son humanos, afectivos, incluso familiares, como bien refleja el fenómeno del mestizaje, otro rasgo característico y distintivo de la civilización española.

Muchas de las expediciones del Pacífico, partirán ya desde los territorios españoles en América. Es muy pertinente recordar, como hace Marías, que, a las expediciones de Colón, de Magallanes y de Elcano, siguieron otras muchas expediciones, acaso menos conocidas, pero no menos relevantes y exitosas, en la exploración del Océano Pacífico. Son muy relevantes las llevadas a cabo por Álvaro de Mendaña, partiendo ya de Lima, la capital del Virreinato del Perú que alcanzó en su primera expedición oceánica las islas Salomón y las Marshall (1568) y lo hizo en unas embarcaciones que llevaban los significativos nombres de Los Reyes y Todos los Santos, de nuevo las referencias monárquica y católica.

En su segunda expedición por el Pacífico, Mendaña, alcanzó las Islas Marquesas (1595), las de San Bernardo (actuales Islas Cook), de nuevo, las Salomon (1595), la isla de Guam (1596) y Manila (1596). Fue una accidentada travesía que, tras un motín, e incluso el fallecimiento por enfermedad del propio Mendaña, hubo de ser culminada por su esposa, Isabel de Barreto. Es una gesta

${ }^{126}$ MARÍAS, J., España inteligible. Razón histórica de las Españas, Alianza Editorial, Madrid, 2014, pp.177-8

${ }^{127}$ Ibidem.

${ }^{128}$ Quizá la única excepción sea Australia, porque, aunque la buscan, la referencian y pasan muy cerca de ella, los españoles no consiguen localizarla. 
histórica liderada por una mujer que es poco conocida en España, no así en el extranjero, merced, sobre todo, a la exitosa obra novelada Las islas de la imprudencia $^{129}$, que le dedicó el erudito escritor británico Robert Graves, autor entre otros del célebre Yo, Claudio $^{130}$.

Es un proceso descubridor y explorador que Marías no duda en calificar de "absolutamente inverosímil"131, cuanto más se estudia y más se profundiza en el mismo, "menos se entiende" $" 132$. Una demostración increíble de eficacia. Ello le lleva al filósofo a preguntarse:

"¿Qué ha ocurrido para que se dispare en breve tiempo tal suma de eficacia? Es uno de los conceptos favoritos de la época moderna, que se expresa con diferentes palabras (performance, Leistung, rendimiento). El elemento renacentista de la España de los Reyes Católicos y, por supuesto, de Carlos $\mathrm{V}$, se manifiesta en este despliegue sin comparación de eficacia."133

Marías se apercibe de que no tiene punto de comparación con las culturas precedentes, salvo acaso con Roma, o con las restantes naciones del momento, salvo acaso con Portugal:

"Solamente Portugal, una vez más, resulta equivalente en la expansión descubridora; pero ni siquiera Portugal representa algo parecido en profundidad de penetración, transformación de los territorios y las sociedades indígenas, edificación de ciudades, establecimiento de nuevos países."134

La exploración portuguesa no comportó un factor civilizador tan intenso como el que sí exhibió la española. Por todo ello, concluye Marías:

"La acción española desde fines del siglo XV hasta mediados o fines del XVI es rigurosamente incomprensible si la medimos con la eficacia de la misma España hasta entonces o con la de cualquier otro país europeo (y tal vez su conjunto si tomamos la Península Ibérica íntegra). Solamente el reconocimiento de esa ininteligibilidad puede permitir superarla, si hacemos intervenir otros factores, específicamente humanos e históricos, es decir, los proyectos como algo capaz de alumbrar fuentes de energía que sin ellos no

${ }^{129}$ GRAVES, R., The isles of Unwisdom, Doubleday, New York, 1949 (edición americana) The Isles of Unwisdom.: Cassell, London, 1950 (edición británica). Traducido al español bajo el título Las islas de la imprudencia.

${ }^{130}$ Idem, I, Claudius, Arthur Barker, Londres, 1934.

${ }^{131}$ MARÍAS, J., España inteligible. Razón histórica de las Españas, Alianza Editorial, Madrid, 2014, p.178.

${ }^{132}$ Ibidem.

${ }^{133}$ Ibidem.

${ }^{134}$ Ibidem. 
existirían. Lo irreal, lo imaginado y deseado, resulta inesperadamente el factor capital de la realidad humana, y por tanto de la historia."

Marías pone de relieve que la acción exploradora y descubridora española, al inicio de la Edad Moderna, resulta tanto más sorprendente e increíble cuando uno se apercibe de los medios dispuestos, pero, sobre todo, de los medios disponibles. Se hace todavía más difícil comprender la grandeza de lo realizado cuando se profundiza realmente en las circunstancias, los medios y las posibilidades desde las que se realizó. Luego, la ininteligibilidad forma parte, necesaria y paradójicamente, de las condiciones de inteligibilidad de lo realizado.

\section{CONCLUSIONES}

Como resumen de todo lo expuesto, creemos poder concluir que por todos los datos disponibles que obran sobre la vida de Magallanes en las fuentes acreditadas de nuestra nación, sintetizadas y avaladas por la Real Academia de la Historia, Fernando de Magallanes es un marino, nacido en Sabrosa, natural de Portugal, que se desplaza a España con una finalidad de instalación en nuestra nación. Esta circunstancia se ve refrendada y avalada por los hechos de contraer matrimonio en Sevilla, tener descendencia en Castilla, castellanizar su nombre y apellido, otorgar testamento en Sevilla en favor de su hijo Rodrigo y su futura descendencia castellana, y por contraer un compromiso de servicio a la Corona Española, estipulado y recogido en las Capitulaciones de Valladolid, que cumple rigurosamente hasta sus últimas y fatales consecuencias. Por lo tanto, podemos afirmar que Magallanes es un naturalizado español -lo que hoy denominamos un nacionalizado español-, que, instalado en nuestra nación y comprometido con ella, la sirve con lealtad hasta los últimos momentos de vida. Parece fundado y de justicia con su persona, reconocerle esta circunstancia y los méritos aparejados, máxime en una persona que sirvió a nuestra nación con honor, hasta las últimas y fatales consecuencias, al margen de los intereses políticos del momento o las controversias interesadas.

La expedición que realiza la primera circunnavegación de la Tierra es una empresa española, auspiciada y financiada por la Corona Española, mediante un procedimiento de financiación mixto que combina capital privado, representado en la persona de Cristóbal de Haro, y de la Iglesia, en la persona del Obispo de Burgos, D. Juan Rodríguez de Fonseca, pero también de la Corona Española que corre con la mayor parte de los gastos de la expedición y la retribución de sus protagonistas. 
La negociación para obtener la financiación constituye un momento clave para conseguir el patrocinio de la Corona a la empresa circunnavegadora. En ella parece decisiva la presencia e implicación de los financiadores burgaleses: Cristóbal de Haro que conoce perfectamente el bagaje personal y profesional de Magallanes al servicio de la Corona de Portugal, al que sigue desde su estancia en Lisboa durante 37 años; y del Obispo de Burgos, Juan Rodríguez de Fonseca, que también respalda, participa y avala el proyecto. La presencia y el respaldo de la Iglesia es fundamental para conseguir el beneplácito de la Corona y la implementación de la expedición.

En el apoyo de la Corona resulta decisivo el hecho de que Magallanes convence al Rey Carlos I de que las islas de la Especiería, a la que denominaban Maluco (las Molucas), pueden estar en territorios que quedarían bajo soberanía española de acuerdo con las jurisdicciones establecidas en el Tratado de Tordesillas. La Corona exige respeto a la legalidad internacional vigente en la época, y la expedición la asume y la cumple, como bien ha recordado Felipe VI en la reciente conmemoración del V Centenario.

Portugal trata de sabotear e impedir la expedición desde su mismo origen. El propio Magallanes llega a España contrariado y repudiado desde Portugal, algunos lo consideran un exiliado, y se asienta en España que le acoge y le brinda trabajo y la oportunidad de realizar el proyecto de su vida al servicio de la Corona española.

Portugal intenta boicotear la expedición desde el conocimiento mismo de su concepción, en suelo español a través de altos representantes lusos en nuestra nación, tanto el embajador de Portugal, D. Alvaro Da Costa, como el factor en Andalucía del rey portugués, D. Manuel, Sebastián Álvarez. La nación lusa actúa en defensa de sus legítimos intereses, como España lo hace en defensa de los suyos. Ambas naciones rivalizan, aunque respetan la legalidad internacional de la época, establecida en el Tratado de Tordesillas.

Magallanes además argumenta la legitimidad de la pretensión de la empresa, asegura a Carlos I que la Isla de la Especiería queda bajo soberanía española con estricto respeto a la legalidad internacional fijada en Tordesillas. Creemos que estos tres factores: el interés e implicación del bien relacionado negociante Cristóbal de Haro, el aval de la Iglesia, representada por el Obispo de Burgos, y el convencimiento de Magallanes de que las Islas de las Especias se encuentren situadas en territorios de potestad española de acuerdo con la legalidad internacional, son factores decisivos del respaldo de la Corona a la empresa.

La expedición realizó importantísimos descubrimientos como la demostración efectiva de la esfericidad de la Tierra, de la que muchos todavía dudaban al inicio de la Edad Moderna. Es la constatación de una evidencia no 
intuitiva como bien han destacado epistemólogos como Thomas S. Kuhn o Gustavo Bueno. Con ello la expedición reconfiguró la imagen del mundo, ya en su época, y, sobre todo, para la posteridad. Además, realizaron descubrimientos geográficos, cartográficos y náuticos decisivos como el Estrecho de Magallanes que comunica el Océano Atlántico con el Pacífico, hito cartográfico fundamental para la navegación transoceánica hasta la construcción del Canal de Panamá ya en 1914.

Descubrieron la condición oceánica del Mar del Sur, al que rebautizaron como Pacífico por las inusuales condiciones climatológicas que encontraron, realmente excepcionales, en una travesía oceánica que fue mucho más larga de cualquier posible previsión. Abrieron nuevas rutas de comunicación y comercio hacia las Indias, con rumbo Oeste, que vinieron a sumarse a las ya existentes: la tradicional Ruta de la Seda por Oriente Medio y la Ruta del Cabo bordeando África abierta por los portugueses.

Descubrieron nuevos pueblos y nuevas culturas hasta entonces desconocidos, con los que convivieron y cooperaron pacíficamente, salvo contadas excepciones, como en Mactán, donde encontró la muerte Magallanes. Realizaron importantes descubrimientos de astronomía como la galaxia que lleva su nombre, la Gran Nube de Magallanes, que no pudo ser referenciada antes por la astronomía clásica o la ciencia de la época, al no resultar observable desde latitudes mediterráneas. También referenciaron nuevas especies de animales y plantas entonces desconocidos, fauna y flora novedosa y de diversas latitudes, que referenciaron y describieron.

Muy a su pesar, descubrieron también nuevas enfermedades, algunas derivadas de carencias dietéticas y nutricionales como el escorbuto, una forma de avitaminosis $\mathrm{C}$, por no consumir alimentos frescos durante periodos prolongados, enfermedad que padecieron y referenciaron en toda su sintomatología.

Por último, pero no menos importante, llevaron la fe y la esperanza cristiana a pueblos y culturas de todo el mundo, haciendo del mensaje cristiano un acontecimiento universal, realmente católico en el más amplio y riguroso sentido de la expresión. Si la impronta de la civilización española al inicio de la Edad Moderna tuvo un carácter expansivo y civilizador, como bien precisó Julián Marías, fue porque era católica y evangelizadora.

La expedición constituye, además, una gesta humana, por los medios con que contaron, las penalidades que hubieron de padecer y las dificultades a las que hubieron de sobreponerse. Resulta ininteligible, dados los limitados medios con que contaban, sin hacer referencia a la dimensión religiosa y a la escala de valores de sus protagonistas. Creemos que son factores relevantes en muchos aspectos que hoy pueden resultar incomprensibles para muchos: el sentido del 
honor, la lealtad, la vulnerabilidad y el temor ante las fuerzas naturales, el compromiso con la palabra dada, el sentido del decoro, el respeto por los seres humanos diferentes en razón de su filiación divina, el sentido de la trascendencia de la propia vida, el sacrificio personal al servicio de una causa mayor, el temor de Dios, la confianza y el abandono en su Providencia. Por más que tuvieran momentos de debilidad, de enfermedad, incluso de rebelión ante circunstancias extremas, que también fueron reflejados por el propio cronista Pigafetta, esta escala de valores estuvo presente, imperó y, como tal, quedó referida. Creemos que es un factor importante, desde luego presente y constatable, pero, además, relevante en la determinación y resistencia humana que mostró la tripulación y que permitió la culminación de la empresa.

La realización de la expedición también precisó de una superación de los mitos y relatos fantásticos que dominaban el imaginario colectivo de la época, especialmente entre el vulgo y la tripulación, y en ello la fe cristiana, que anuncia al Dios del Logos frente a las supersticiones y los mitos, una fe abierta a la esperanza y a la confianza en la Providencia divina, con un sentido trascendente de la propia vida, en el marco referencial de una cosmovisión cristiana, fueron factores relevantes, seguramente decisivos, en el éxito de la expedición.

Creemos que la Primera Circunnavegación de la Tierra constituye una gran gesta de la humanidad protagonizada por nuestra nación al inicio de la Edad Moderna, que solo se comprende en toda su dimensión y significado desde las condiciones políticas, económicas, científicas, culturales y religiosas que la hicieron posible, desde las trayectorias históricas en que se produjeron los hechos acontecidos y sus amplias repercusiones. Aunque, como bien constata Julián Marías, cuánto más se profundiza en ellos, y en el horizonte cultural y civilizador que ellos abrieron, más sorprendentes e inverosímiles resultan. En todo caso, ya nunca será posible un hito igual, no solo porque ya no podrá darse, sino porque la trascendencia y repercusión que tuvieron, que significó una reconfiguración de la imagen del mundo, ya en su época y para la posteridad, siempre será irrepetible: «Primus circumdediste me». 


\section{BIBLIOGRAFÍA}

\subsection{Bibliografía empleada}

ALONSO CABELlOS, A., Magallanes y Elcano: Primus circumdediste me, Sevilla, 2016.

BERNABÉU, S., "Magallanes: Retrato de un hombre". En YUSTE LÓPEZ, C.; PINZÓN RÍOS, G., A 500 años del hallazgo del Pacifico. La presencia novohispana en el Mar del Sur, Ciudad de México, Universidad Nacional Autónoma de México, Instituto de Investigaciones Históricas, 2016. Disponible en http://www.historicas.unam.mx/publicaciones/publicadigital/libros/hallazgo_paci fico/novohispana.html

BUENO G., La teoría de la Esfera y el Descubrimiento de América, disponible en $\mathrm{http} / / / \mathrm{www}$.filosofia.org/rev/bas/bas20101.htm

BUENO, G., España no es un mito. Claves para una defensa razonada, Temas de Hoy, Madrid, 2005.

COMELLAS GARCÍA-LLERA, JL, La primera vuelta al mundo, Rialp, Madrid, 2012.

DE BRY T., América, 1590-1634, prólogo de John H. Elliott, Madrid, Siruela, 1992.

FELIPE VI, Palabras de su Majestad El Rey con motivo de la conmemoración de las Capitulaciones de Valladolid. Monasterio de Nuestra Señora de Prado. Valladolid, 22 de marzo 2018. Disponible en:

http://www.casareal.es/GL/Actividades/Paginas/actividades_discursos_detalle.aspx? data $=6018$

FERNÁNDEZ NAVARRETE, M., SALVÁ, M. y SAINZ DE BARANDA, P. (Miembros de la Academia de Historia), Colección de documentos inéditos para la historia de España. (Vol. I), Documentos relativos a Juan Sebastián del Cano, De la Viuda, Madrid, 1942.

FERNÁNDEZ-SHAW, C.M., Connotaciones españolas en el Pacífico austral. En INSTITUTO DE HISTORIA Y CULTURA NAVAL, XIII Jornadas de Historia Marítima: Álvaro de Mendaña: el Pacífico y su dimensión histórica. Cuadernos Monográficos del Instituto de Historia y Cultura Naval, n²6, Madrid, 1995

GIL FERÁNDEZ, J., El exilio portugués en Sevilla. De los Braganza a Magallanes. Sevilla, Fundación Cajasol, 2009.

GONZÁLEZ FERNÁNDEZ, E, Filosofía política de la corona en Indias. La Monarquía Española y América. Fundación Ignacio Larramendi, $3^{\mathrm{a}}$ ed., Fundación Ignacio Larramendi, Madrid, 2010

GRAVES, R., I, Claudius, Arthur Barker, Londres, 1934.

GRAVES, R., The isles of Unwisdom, Doubleday, New York, 1949.

HIGUERAS RODRÍGUEZ, MD., La dieta de vuelta al mundo. Alimentos básicos a bordo en el siglo XVI, en volumen monográfico «El viaje de los alimentos. Expediciones, descubrimientos y conquistas que produjeron el intercambio de 
alimentos entre distintos continentes», Sociedad Geográfica Española, $n^{\circ}$ 62, enero-abril, 2019.

HUXLEY BARKHAM, S., «The Mentality of the men behind the sixteenth-century Spanish Voyage to Terranova». En WARKENTIN, G.; PODRUCHNY, C. Decentring the Renaissance: Canada and Europe in Multidisciplinary Perspective, 1500-1700. University of Toronto Press, Toronto, 2001.

KUHN, T.S., The Structure of Scientific Revolutions (1962) International Encyclopedia of Unified Science, Editor-in-Chief: Otto Neurath, Associate Editors: Rudolf Carnap Charles Morris. The University of Chicago Press, Chicago, 1970.

MARÍAS, J., España inteligible. Razón histórica de las Españas (1985), Alianza Editorial, Madrid, 2014.

MARTÍNEZ SHAW, C., Después del Cano. Repercusiones de la primera circunnavegación. En web V Centenario de la I Vuelta al Mundo, disponible en $\mathrm{http} / / /$ vcentenario.es/

PIGAFETTA, A., Primer viaje alrededor del globo. La crónica en vivo de la expedición de Magallanes-Elcano 1519-1522, Civiliter, Sevilla, 2012.

REAL ACADEMIA DE LA HISTORIA, Informe sobre la Primera Circunnavegación a la tierra, 10 de marzo de 2109. Disponible en http://www.rah.es/informe-dela-real-academia-de-la-historia-sobre-la-primera-circunnavegacion-a-la-tierra/

SÁNCHEZ GARCÍA JL, Compromiso con la superación del hambre en el mundo: por una nueva humanidad. Presentación del volumen. En

SÁNCHEZ GARCÍA, JL. (dir. y coord.) Superación del hambre en el mundo: Por una Nueva Humanidad. Estudio Interdisciplinar, Thomson-Reuters Aranzadi, Pamplona, 2017.

SÁNCHEZ GARCÍA, JL., DÍEZ SANZ, JM., y PÉREZ RUIZ, S., "La discapacidad capacita, proyecto y tarea: el desarrollo de las capacidades humanas". En IBÁÑEZ MARTÍN, J.A., y FUENTES, J.L., (edit.) Educación y capacidades. Hacia un nuevo enfoque del desarrollo humano. Ed. Dykinson, Madrid, 2017.

SPATE, O.H.K., The Spanish Lake, The Australian National University, Camberra, 2004.

\subsection{Bibliografía consultada}

ALVAR, A., Juan Sebastián Elcano (1476?-1526), La Trébere, Madrid, 2016.

ANDAYA, L. Y., "Los primeros contactos de los españoles con el mundo de las Molucas en las Islas de las Especias". Revista de Estudios del Pacífico, 11, 1992, pp. 61-84.

ARGENSOLA, B. L., Conquista de las islas Molucas, Miraguano, Madrid, 2009.

BAERT, A., "Itinerario de la Vuelta al Mundo de Magallanes y Elcano", en CRIADO DE VAL, M. (dir.): Atlas de Caminería Hispánica, II. Fundación de la Asociación Española de Carreteras, Colegio de Ingenieros de Caminos, Canales y Puertos, Madrid, 2011, pp. 92-97. 
BECCO, H., Crónicas de los Patagones, Fundación Biblioteca Ayacucho, Buenos Aires, 2003.

BERNABÉU ALBERT, S., La aventura de lo imposible. Expediciones marítimas españolas, Lunwerg, Barcelona, 2000.

CASTRO, X. de; Hamon, J.; Thomaz, L. F. (eds.) (): Le Voyage de Magellan (15191522). La relation d'Antonio Pigafetta et autres témoignages, Chandeigne, Paris, 2007.

FERNÁNDEZ DE NAVARRETE, M., Colección de los viajes y descubrimientos que hicieron por mar los españoles desde fines del siglo XV., Atlas, Madrid, 1964.

FERNÁNDEZ VIAL, I.; FERNÁNDEZ MORENTE, G., La primera vuelta al mundo. La nao Victoria, Muñoz Moya ed., Sevilla, 2001.

FERNÁNDEZ CHAVES M.F.; PÉREZ GARCÍA R.M., La penetración económica portuguesa en la Sevilla del siglo XVI, UNED. Espacio, Tiempo y Forma, Serie IV, Historia Moderna, t. 25, 2012, pp. 199 - 222.

FIRBAS, P. (): "Fracaso, derrota y épica: las poblaciones del estrecho de Magallanes (1584-1587)". Iberomania, $n$. 58, 2003, pp. 126-137.

GARCIA, J. M., A viagem de Fernão de Magalhães e os portugueses. Presença, Lisboa, 2007.

GIL FERNÁNDEZ, J., "De Sevilla a Lisboa: Aspectos de una relación secular”, Portuguese Studies, 8 (Londres, 1992): 40/56.

IGNACIO FERNÁNDEZ VIDAL Y G. FERNÁNDEZ MORENTE. La primera vuelta al mundo, La Nao Victoria. Sevilla, 2001.

J. LYNCH. Los Austrias 1516-1700. Crítica, Barcelona, 2000.

KELSEY, H., Sir Francis Drake. The Queen's Pirate. Yale University Press, New Haven/ London, 1998.

MARTINIC, M., Historia del estrecho de Magallanes. Santiago de Chile: Editorial Andrés Bello, 1977.

PERÉZ-MALLAÍNA, P. E., Los hombres del océano. Vida cotidiana de los tripulantes de las flotas de Indias. Siglo XVI, Diputación provincial de Sevilla, Sevilla, 1992.

PIGAFETTA, A.; DE RIQUER, I. (ed.), El primer viaje alrededor del mundo. Relato de la expedición de Magallanes y Elcano, Ediciones B. Yuste López, C., Barcelona, 1999.

PINZÓN RÍOS, G. (coord.), A 500 años del hallazgo del Pacífico. La presencia novohispana en el Mar del Sur. México: Universidad Nacional Autónoma de México, 2016.

SÁNCHEZ, A., La espada, la cruz y el Padrón. Soberanía, fe y representación cartográfica en el mundo ibérico bajo la Monarquía Hispánica, 1503-1598, Madrid, CSIC, 2013.

STEFAN ZWEIG. Magallanes: El hombre y su gesta. Editorial Debate, Madrid, 2005.

TEMPÈRE, D., Vivre et mourir sur les navires du Siècle d'Or, Pups, París, 2009.

TEXEIRA DA MOTA, A., A viagem de Fernão de Magalhães e as questão das Molucas. Lisboa: Junta de Investigações Científicas do Ultramar, 1975.

VV.AA., Desvelando horizontes. La circunnavegación de Magallanes y Elcano. 3 tomos. Madrid: Fundación Museo Naval, 2018-2019. 